\title{
Reawakening of dormant estrogen- dependent human breast cancer cells by bone marrow stroma secretory senescence
}

\author{
Samir Tivari ${ }^{1}$, Haiyan Lu', Tanya Dasgupta ${ }^{1}$, Mariana S. De Lorenzo ${ }^{2}$ and Robert Wieder ${ }^{*}$ (D)
}

\begin{abstract}
Background: Dormant estrogen receptor positive (ER+) breast cancer micrometastases in the bone marrow survive adjuvant chemotherapy and recur stochastically for more than 20 years. We hypothesized that inflammatory cytokines produced by stromal injury can re-awaken dormant breast cancer cells.

Methods: We used an established in vitro dormancy model of Michigan Cancer Foundation-7 (MCF-7) breast cancer cells incubated at clonogenic density on fibronectin-coated plates to determine the effects of inflammatory cytokines on reactivation of dormant ER+ breast cancer cells. We measured induction of a mesenchymal phenotype, motility and the capacity to re-enter dormancy. We induced secretory senescence in murine stromal monolayers by oxidation, hypoxia and estrogen deprivation with hydrogen peroxide $\left(\mathrm{H}_{2} \mathrm{O}_{2}\right)$, carbonyl-cyanide mchlorophenylhydrazzone (CCCP) and Fulvestrant (ICl 182780), respectively, and determined the effects on growth of co-cultivated breast cancer cells.
\end{abstract}

Results: Exogenous recombinant human (rh) interleukin (IL)-6, IL-8 or transforming growth factor $\beta 1$ (TGF $\beta 1$ ) induced regrowth of dormant MCF-7 cells on fibronectin-coated plates. Dormant cells had decreased expression of E-cadherin and estrogen receptor a (ERa) and increased expression of N-cadherin and SNAI2 (SLUG). Cytokine or TGF $\beta 1$ treatment of dormant clones induced formation of growing clones, a mesenchymal appearance, increased motility and an impaired capacity to re-enter dormancy. Stromal injury induced secretion of IL-6, IL-8, upregulated tumor necrosis factor alpha (TNFa), activated TGF $\beta$ and stimulated the growth of co-cultivated MCF-7 cells. MCF-7 cells induced secretion of IL-6 and IL-8 by stroma in co-culture.

Conclusions: Dormant ER+ breast cancer cells have activated epithelial mesenchymal transition (EMT) gene expression programs and downregulated ERa but maintain a dormant epithelial phenotype. Stromal inflammation reactivates these cells, induces growth and a mesenchymal phenotype. Reactivated, growing cells have an impaired ability to re-enter dormancy. In turn, breast cancer cells co-cultured with stroma induce secretion of IL-6 and IL-8 by the stroma, creating a positive feedback loop.

Keywords: Breast cancer, Dormancy, Bone marrow stroma, Secretory senescence, Epithelial mesenchymal transition

\footnotetext{
* Correspondence: wiederro@njms.rutgers.edu

${ }^{1}$ Department of Medicine, Rutgers New Jersey Medical School and Rutgers Cancer Institute of New Jersey, 205 South Orange Avenue, Cancer Center H1216, Newark, NJ 07103, USA

Full list of author information is available at the end of the article
}

(c) The Author(s). 2018 Open Access This article is distributed under the terms of the Creative Commons Attribution 4.0 International License (http://creativecommons.org/licenses/by/4.0/), which permits unrestricted use, distribution, and reproduction in any medium, provided you give appropriate credit to the original author(s) and the source, provide a link to the Creative Commons license, and indicate if changes were made. The Creative Commons Public Domain Dedication waiver (http://creativecommons.org/publicdomain/zero/1.0/) applies to the data made available in this article, unless otherwise stated. 


\section{Background}

Breast cancers metastasize early, as soon as cells with diminished cohesion enter the circulation through newly formed, leaky blood vessels $[1,2]$. They undergo massive attrition, but some survive and settle in distant organs such as bone marrow, where their numbers are further reduced by a hostile environment. The ones that survive have tumor initiating capacity [3], become dormant and undetected for years [4] and are resistant to adjuvant chemotherapy administered with the very intent of eliminating them [5]. Dormancy occurs primarily in estrogen receptor positive $(\mathrm{ER}+)$ breast tumors [6]. Dormant cells continue to reactivate for decades in a stochastic manner, consistent with a microenvironment-dependent process. Most recur years after adjuvant antiestrogen therapy or menopause, suggesting that estrogen deprivation may adversely affect the microenvironment's ability to support dormancy $[7,8]$.

Dormancy is considered as either tumor mass dormancy or cellular dormancy [9]. Tumor mass dormancy maintains a balance between proliferation and cell death through limiting blood supply and immune suppression. Cellular dormancy maintains cells at the single or oligocellular level by inhibiting cell division and promoting re-differentiation through interactions with the microenvironment. The latter may also apply to tumor mass dormancy [9]. Many mechanisms for inducing and escaping cellular dormancy have been identified, which vary with different metastatic microenvironments and the different origins of primary tumors [10].

Early and late primary tumors result in disseminated bone marrow metastases with differing gene expression signatures [11]. Macrophages in premalignant lesions may induce epithelial-mesenchymal transition (EMT) and metastasis [12] and micrometastases from late, hypoxic tumors are already preprogrammed to be resistant to therapy [13].

The bone marrow microenvironment induces tumor dormancy through multiple mechanisms and contains many types of stromal cells that interact with disseminated cancer cells [14]. Studies suggest that dormant micrometastases can usurp the hematopoietic stem cell niche $[15,16]$, but both endosteal osteoblasts and non-cycling endothelial niches support dormancy [17]. Redundant dormancy-inducing signals derive from high levels of all-trans retinoic acid (ATRA), transforming growth factor- $\beta-2$ (TGF $\beta) 2$, bone morphogenic protein (BMP)-7 and a hypoxic environment in the bone marrow [17]. Hypoxia induces glucose transporter-1 (GLUT1) and hypoxia-inducible factor 1- $\alpha$ (HIF1 $\alpha)$, key dormancy genes nuclear receptor subfamily 2 group $\mathrm{F}$ member 1 (NR2F1), which is an orphan nuclear retinoid receptor, DEC2, a basic helix-loop-helix transcription repressor involved in circadian rhythm, cyclin dependent kinase (CDK) inhibitor $\mathrm{p} 27^{\mathrm{Kip} 1}$ and chemoresistance in ER+ breast cancer cells [17]. Leukemia inhibitory factor (LIF) provides dormancy signals through signal transducer and activator of transcription protein-3 (STAT3) and suppressor of cytokine signaling 3 (SOCS3) [18]. Osteoblasts [19] and hypoxia [20] induce dormancy through AXL receptor tyrosine kinase $(\mathrm{Axl})$ and its ligand growth arrest-specific 6 (GAS6) and increased TGF $\beta 2$ and its receptor [13]. ATRA also induces NR2F1 and TGF $\beta 2$ and mediates quiescence through transcription factor SOX9, retinoic acid receptor $\beta(R A R \beta)$ and CDK inhibitors [21]. NR2F1 also acts through global chromatin repression and the pluripotency gene NANOG [21].

TGF $\beta 2$ induces dormancy through stress-activated mitogen-activated protein kinase p38 signaling, which upregulates dormancy-associated proteins DEC2 and $\mathrm{p} 27^{\text {Kip1 }}$ [22]. High ratios of activated p38/ERK induce p38-mediated survival and dormancy signaling through activating transcription factor (ATF)/Ras homolog enriched in brain (RHEB)/mammalian target of rapamycin (mTOR) [23] and dormancy-associated transcription factors DEC2, p27 ${ }^{\mathrm{Kip} 1}, \mathrm{p} 21^{\mathrm{WAF} 1}$ and NR2F1 [21, 22]. p38 can be activated by urokinase-type plasminogen activator (uPA), fibronectin and integrins [24, 25]. BMP-7, a TGF $\beta$ family member secreted by stromal cells, can also induce reversible dormancy through induction of p38 signaling and upregulation of the metastasis suppressor gene N-myc downregulated gene 1 (NDRG1) [26].

Relapse after years of dormancy remains a significant medical problem. In the perivascular niche, non-dividing endothelial cells promote dormancy through thrombospodin-1 but sprouting neovascular endothelial cell tips promote micrometastatic outgrowth through TGF $\beta 1$ and periostin [27]. Estrogen depletion, associated with tumor relapse [7, 8] induces Angiopoietin-2, which destabilizes endothelial cell-cell junctions by disrupting Tie2 receptor and increases tumor cell surface integrin $\beta 1$ [28]. Estrogen depletion also induces secretion of interleukin-6 (IL-6) by metastatic cells in an autocrine manner through IL-6/Stat3/neurogenic locus notch homolog protein 3 (Notch3) and reactivation into a hormone resistant population [3]. Osteoclast activity induced by receptor activator of nuclear factor kappa-B ligand (RANKL) can also release dormant endosteal breast cancer micrometastases through vascular cell adhesion molecule 1 (VCAM-1) expression on the cancer cells $[29,30]$. Fibrosis and Colagen-1 induce dormant cell reawakening [31]. ER+ dormant breast cancer cells expressing lysyl oxidase homolog 2 (LOXL2) acquire stem-like characteristics that depend on epithelial mesenchymal programs to mediate exit from dormancy [32]. Epigenetic events in the dormant microenvironment may also dictate awakening from dormancy [33].

We demonstrated a role for fibroblast growth factor-2 (FGF-2), which is abundant on the marrow stroma extracellular matrix, in the dormancy of ER+ breast cancer cells 
[34]. FGF-2 induces $G_{1}$ cell cycle arrest [35], partial re-differentiation of ER+ cells and re-expression of integrin $\alpha 5 \beta 1$, a receptor for fibronectin also abundant in the marrow [34]. FGF- 2 and integrin $\alpha 5 \beta 1$ initiate survival signaling through phosphoinositol-3 kinase (PI3K) and microtubule-associated protein kinase (MAPK) [34, 36]. They inactivate the small guanosine triphosphatase (GTPase) RhoA through membrane localization of the Rho GTPase activating protein (GAP) GTPase Regulator Associated with the Focal Adhesion Kinase pp125(FAK) (GRAF) [37], resulting in cortical redistribution of fibrillar actin (F-actin) and a characteristic large, flat dormant cell phenotype with large cytoplasm to nucleus ratios.

Because of a required close association with stroma, we hypothesized that continued "health" of the bone marrow stroma is key to maintaining dormancy. Potential injury to stromal cells over many years, aging and estrogen deprivation during menopause may result in secretory senescence [38], characterized by production of inflammatory cytokines able to reawaken dormant cancer cells.

Several observations support this hypothesis. Constitutive secretion of interleukin (IL)- 6 by cultured bone marrow stroma positively correlates with age, and aging predisposes cells to injury-induced secretory senescence [39]. Hormone replacement lowers secretion of IL-6 and IL-11 [39]. Declines in ATP levels induce apoptosis and promote necrotic inflammation [40] and hydrogen peroxide $\left(\mathrm{H}_{2} \mathrm{O}_{2}\right)$ induces inflammatory cytokines (IL-6, IL-7, IL-16, and IL-17) and necrosis in aging fibroblasts. Aging also eliminates protection from hypoxic or oxidative stress by heat preconditioning-induced heat shock protein 70 (HSP70) in dermal fibroblasts [41] and decreases the HSP70 response and adaptation in rat livers [42].

In turn, senescent fibroblasts promote malignant transformation of co-cultivated premalignant epithelial cells [38]. Aging adipocytes increase cytokine secretion and stimulate tumor growth [43], events with potential impact as the ratio of fat to hematopoietic cells in the marrow increases with age [44]. Here, we test the hypothesis that oxidative, hypoxic and estrogen deprivation-induced bone marrow stromal injury promotes secretory senescence and that cytokines produced by the stroma can reactivate dormant ER+ breast cancer cells in an in vitro dormancy model.

\section{Methods}

\section{Cells}

Human luminal ER $\alpha$-positive MCF-7 breast cancer cell line was obtained from American Type Culture Collection (ATCC) (Manassas, VA, USA) and cultured at $37{ }^{\circ} \mathrm{C}$ at $5 \% \mathrm{CO}_{2}$ Dulbecco's modifies Eagle's medium (DMEM) supplemented with $10 \%$ fetal bovine serum (FBS) (Serum Source International, NC), 1\% penicillin/streptomycin and $1 \% \mathrm{~L}$-glutamine (Corning, Corning, NY) as before [35]. The cell line was authenticated by the Rutgers New
Jersey Medical School Molecular Resource Facility and demonstrated a 93\% match to the ATCC cell line HTB-22 (Human MCF-7 Breast Adenocarcinoma).

\section{Supplies and reagents}

Tissue culture- and fibronectin-coated plates were purchased from Corning (Corning, NY). Recombinant human (rh)FGF-2, rhIL-6, rhIL-8 and rhTGFß1 and mouse blocking monoclonal antibody to CXCL1/KC (IL-8) and mouse immunoglobulin G (IgG) were purchased from R\&D Systems (Minneapolis, MN). $\mathrm{H}_{2} \mathrm{O}_{2}$, carbonyl-cyanide m-chlorophenylhydrazzone (CCCP) and Fulvestrant (ICI 182780) were purchased from Sigma-Aldrich (Saint Louis, MO). Radioimmunoprecipitation assay (RIPA) buffer was purchased from Santa Cruz Biotechnology (Santa Cruz, CA). Rabbit monoclonal antibodies to human E-Cadherin (clone 24E10), N-Cadherin (clone D4R1H) XP), Slug (clone C19G7), $\beta$-Catenin (clone D10A8) were purchased from Cell Signaling (Danvers, MA). Mouse monoclonal antibody to estrogen receptor $\alpha(\mathrm{ER} \alpha)$ (clone F-10), N-cadherin (clone H-4), horseradish peroxidase (HRP)-labeled goat anti-rabbit IgG and goat anti-mouse IgG were purchased from Santa Cruz Biotechnology (Santa Cruz, CA). Vybrant CM-DiI fluorescent tracking dye was purchased from Invitrogen-Molecular Probes (Carlsbad, CA).

\section{Primary bone marrow stroma (BMS)}

Animal studies were approved by the Institutional Animal Care and Use Committee. Human bone marrow aspirates were obtained under an Institutional Review Board-approved protocol after informed consent. Bone marrow stroma was prepared from mouse and human bone marrow, as reported [34, 45]. Single cell suspensions of bone marrow hematopoietic progenitors, bone marrow flushed from mouse femurs and buffy coats from human aspirates were cultured in $25-\mathrm{cm}^{2}$ flasks in Gartner's Medium at 1.5 to $3 \times 10^{6}$ cells $/ \mathrm{cm}^{2}$ at $37^{\circ} \mathrm{C}$ and $5 \% \mathrm{CO}_{2}$. The medium and non-adherent cells were demi-depleted every 7 days and replaced with fresh medium until adherent stroma reached approximately $50-75 \%$ confluence. Stroma were detached by trypsin treatment, distributed into 24-well tissue culture-coated plates at $1-1.5 \times 10^{5}$ cells $/ \mathrm{cm}^{2}$ and cultured to confluence.

\section{Co-cultivation studies}

MCF-7 breast cancer cells were labeled with Vybrant CM-DiI as per manufacturer's instructions and their clonogenic efficiency for forming growing and dormant clones on fibronectin-coated tissue culture plates was confirmed to be identical to that of unlabeled cells. Prior to co-incubation, confluent stromal monolayers on quadruplicate wells of 24 well plates were treated with variable concentrations of $\mathrm{H}_{2} \mathrm{O}_{2}$ and $\mathrm{CCCP}$ in fetal calf serum-free DMEM or with DMEM alone as control for 
one hour, washed twice with DMEM/10\% FCS and incubated with one thousand Vybrant CM-Dil-labeled MCF-7 cells in one ml DMEM/10\% FCS for six days at $37{ }^{\circ} \mathrm{C} 5 \% \mathrm{CO}_{2}$. For experiments designed to inhibit estrogen signaling, the Gartner's medium was aspirated from confluent stroma wells and replaced with 1000 MCF-7 cells in either $1 \mathrm{ml}$ phenol red-free DMEM/10\% FCS with ICI 182780 at various concentrations or in $1 \mathrm{ml}$ phenol red-free DMEM/10\% FCS as control, and were incubated for 6 days. For antibody blocking experiments, $2 \mu \mathrm{g} / \mathrm{ml}$ blocking monoclonal antibody to CXCL1/KC or mouse IgG was included with the MCF-7 cells at the time of incubation. Day 6 embedded colonies and detached spherules were photographed using a Zeiss Axio Observer Z1 Microscope equipped with Zeiss Axiocam MRm Camera (Zeiss, Germany) and counted.

\section{Breast cancer Clonogenic assays on fibronectin-coated tissue culture plates}

MCF-7 cells were incubated at clonogenic density with 1000 or 1500 cells/well in quadruplicate on human fibronectin coated 24 well plates in $1 \mathrm{ml}$ DMEM/10\% FCS and allowed to adhere overnight $[34,46]$. The next day, wells were supplemented with $100 \mu \mathrm{l}$ of $100 \mathrm{ng} / \mathrm{ml}$ of FGF-2 for a final concentration of $10 \mathrm{ng} / \mathrm{ml}$ with or without $10 \mathrm{ng} / \mathrm{ml}$ recombinant human IL-6, IL-8 or TGF $\beta 1$. After 6 days, cells were stained with $0.1 \%$ crystal violet and growing colonies of $\geq 30$ cells and dormant colonies of 2-12 cells were counted. In experiments testing the effects of cytokines on dormant cells, fresh medium or medium containing $10 \mathrm{ng} / \mathrm{ml}$ recombinant human IL- 6 , IL- 8 or TGF $\beta 1$ were added to the day 6 cultures. After an additional 6 days, growing and dormant colonies were counted after fixing in crystal violet.

\section{Western blot analysis}

Cell lysates were prepared as before, analyzed by sodium dodecyl sulfate polyacrylamide gel electrophoresis (SDS-PAGE) and transferred to polyvinylpyrolidone membranes [35]. Indirect immunofluorescence was detected by enhanced chemiluminescence (ECL) and equal loading was confirmed by stable abundant protein bands on Coomassie Blue-stained membranes.

\section{Enzyme-linked immunoassay (ELISA}

Mouse and human IL- 6 and IL-8 concentrations in murine and human bone marrow stroma conditioned medium were carried out using Mouse IL-6 and Human IL-6 Elisa Kits (BD Biosciences, Franklin Lakes. NJ) and Quantikine Mouse CXCL1/KC and Quantikine Human CXCL8/IL-8 ELISA kits (R\&D Systems, Minneapolis, MN). DMEM/ $10 \%$ FCS was collected from nearly confluent mouse and human stromal monolayers 24, 48 and $72 \mathrm{~h}$ after $\mathrm{H}_{2} \mathrm{O}_{2}$ and CCCP injury and from control plates or after 24 and
$48 \mathrm{~h}$ incubations with ICI 182780 in phenol red-free medium and controls in triplicate in 24 well tissue culture plates. All experiments were done twice and most were done three times. Absolute values of cytokine secretion varied between experiments due to variable length of time needed to generate stromal cultures from mouse bone marrow. However, experimental trends remained consistent from experiment to experiment.

\section{Cell migration}

Cell migration experiments were performed using ACEA xCELLigence system CIM-plates, as described previously [47], according to the manufacturer's instructions. The migration of single cell suspensions of $1 \times 10^{5}$ growing MCF-7 cells and growing MCF-7 cells treated with rhIL-6, IL-8 or TGF $\beta 1$ for 6 days and of dormant MCF-7 cells (MCF-7 cells treated with FGF-2 for 6 days) and dormant MCF-7 cells treated with rhIL-6, IL-8 or TGF $\beta 1$ for an additional 6 days was determined in triplicate. Each experiment was conducted at least twice.

\section{Live cell time lapse imaging}

A time-lapse experiment was performed to image regrowth of individual growing and dormant colonies using a fully motorized Zeiss Axio Observer Z1 Microscope equipped with Zeiss Axiocam MRm Camera (Zeiss, Germany). MCF cells were incubated at 4750 cells/well on fibronectin-coated 6 well plates without and with FGF-2 $10 \mathrm{ng} / \mathrm{ml}$. Day 6 growing clones and dormant clones generated by 6 day incubations with FGF-2 were incubated with fresh DMEM/10\% FCS without or with $10 \mathrm{ng} / \mathrm{ml}$ rhIL-6, rhIL-8 or $\operatorname{rhTGF} \beta 1$ on 6-well fibronectin-coated plates and imaged every $24 \mathrm{~h}$ for 6 additional days. Growing and cytokine-treated colonies were photographed daily by an automated software control using the ZEN imaging software program, which includes a Tiles tool (Zeiss, Germany), permitting time course imaging of individual clones over a large area with the option to zoom-in on regions of interest.

\section{Statistical analysis}

Statistical analyses were performed in Microsoft Excel using student unpaired $t$-test. A $p$-value less than 0.05 was considered statistically significant. Data are presented as mean \pm standard deviations. All experiments were repeated a minimum of two times.

\section{Results}

\section{Reactivation of dormant MCF-7 colonies in an in vitro dormancy model}

Our dormancy model involves incubation of ER+ cells at clonogenic density, where the primary interaction of the cells is with the substratum instead of each other, on fibronectin-coated tissue culture plates in the presence 
of FGF-2 for six days [34]. In response to FGF-2, cells exit the cell cycle, partially re-differentiate, re-express integrins lost with de-differentiation, take on a spread-out appearance with omnidirectional focal adhesion complex activation and cortical redistribution of actin and form colonies of $2-12$ cells. They re-express integrin $\alpha 5 \beta 1$, which binds fibronectin in the substratum and contributes to the FGF-2-mediated survival and re-differentiation signaling that results in the dormant phenotype [34, 36, 37].

We tested the hypothesis that IL-6, IL- 8 and TGF $\beta 1$ could reactivate dormant MCF-7 cells in this well-characterized in vitro model $[34,46]$. Following our standard procedures, we incubated MCF-7 cells at clonogenic density on fibronectin-coated plates with rhFGF-2 for six days and observed the formation of mainly dormant clones, consistent with prior results (Fig. 1a). When these cultures were re-incubated with fresh medium without rhFGF-2, or fresh medium without rhFGF- 2 but with added rhIL-6, rhIL- 8 or rhTGF $\beta 1$ for an additional 6 days, the number of dormant clones was significantly diminished compared to the number on day 6. Instead, the number of growing colonies in cultures incubated with the cytokines or TGF $\beta 1$ was significantly higher than those in the cultures with medium alone (Fig. 1a). In contrast to the effects of the cytokines and rhTGF $\beta 1$ on dormant clones, rhIL- 6 , rhIL- 8 or rhTGF $\beta 1$ did not enhance the growth of growing colonies. However, rhTGF $\beta 1$ did inhibit their formation, in line with our prior observations [48] (Fig. 1b).

Because a small number of growing clones do develop in day 6 rhFGF-2-treated dormant cultures, we followed the fate of single clones to demonstrate unequivocally the capacity of individual dormant clones to reactivate in response to cytokines and TGF $\beta 1$ through time lapse photography using a motorized Zeiss Axio Observer Z1 Microscope. Fig. 1c demonstrates that individual dormant clones are capable of being reactivated into growing clones. The observations also demonstrated that some dormant clones die, some growing clones die and occasional growing clones continue to proliferate.

The appearance of many of the cells in the growing colonies that arose from dormant clones was different than that of the cells in the growing clones that formed from initial incubation of growing MCF-7 cultures for 6 days (Fig. 2a). Many of the reactivated cells appeared fusiform, reminiscent of fibroblasts, and had less inter-cell cohesion. This suggested that some of the reactivated dormant MCF-7 cells may have undergone EMT. We tested this hypothesis. To our surprise, the Western blots demonstrated that before reactivation, dormant cells have already activated their EMT genetic program by downregulation of E-cadherin and upregulation of N-cadherin and SLUG (Fig. 2b). Treatment with cytokines also caused a downregulated expression of
ER $\alpha$ in growing MCF-7 cells and dormant cells stopped expressing it altogether. Dormant cells treated with cytokines and TGF $\beta 1$ also expressed very low levels of ER $\alpha$.

In addition to the phenotypic observations shown, incubation of growing cells with rhIL6, rhIL-8 and rhTGF $\beta 1$ slowed their motility (Fig. 3a), while incubation of dormant cells with rhIL-6 and rhIL8 increased motility (Fig. 3b). In the experiment shown, TGF $\beta 1$ had only a small effect on promotion of dormant MCF-7 cell motility but had a greater effect in other replicate experiments.

\section{Dormant cells or cells reactivated from dormancy have a decreased capacity to re-enter dormancy}

The evidence that dormant cells have already activated their EMT program led us to explore the capacity of dormant cells or dormant cells reactivated with inflammatory cytokines or rhTGF $\beta 1$ to form dormant clones again. Figure 4a demonstrates that dormant clones that were disbursed by trypsinization and reincubated as single cells at clonogenic density have a significantly diminished capacity to form dormant clones. Parenthetically, their growing colony clonogenic potential is also diminished. Growing clones treated with rhIL-6 for 6 days have no change in their growing or their dormant clonogenic potential. Growing clones treated with rhIL- 8 or rhTGF $\beta 1$ on the other hand, have a small but significantly impaired dormant clonogenic potential. To determine the effects of rhIL- 6 , rhIL- 8 and rhTGF $\beta 1$ treatment of dormant clones on their ability to re-form dormant clones, we treated dormant clones for 6 days with rhIL-6, rhIL-8 and rhTGF $\beta 1$, disrupted clones with trypsin to generate single cell suspensions and re-incubated the cells at clonogenic density on fibronectin with and without rhFGF-2. Figure $4 \mathrm{~b}$ demonstrates that dormant clones that were reactivated with either DMEM/ $10 \%$ FCS (D10), rhIL-6, rhIL-8 or rhTGF $\beta 1$ had a very low capacity to form dormant clones, with growing to dormant clone ratios greater than 1 when incubated with FGF-2. These data demonstrate that cells in dormant clones, which have already undergone EMT, have a significantly impaired capacity to re-enter FGF-2-induced dormancy once activated to grow again in our in vitro model.

\section{Stromal injury results in secretion of inflammatory cytokines and activation of TGF $\beta$ and TNFa}

We tested the hypothesis that injury of bone marrow stroma by oxidation, hypoxia or estrogen deprivation could induce secretory senescence. Exposure of human stromal monolayers obtained from several normal volunteers with $\mathrm{H}_{2} \mathrm{O}_{2}$, CCCP or ICI 182780 resulted in highly variable induction of IL- 6 and IL-8 secretion and was found not to be a useful experimental model for our studies. We moved to a biologically less variable model with stroma from $\mathrm{NCr}$ $\mathrm{nu} / \mathrm{nu}$ mice. Our results demonstrated that one hour incubations with $\mathrm{H}_{2} \mathrm{O}_{2}$ at concentrations at or above $50 \mu \mathrm{m}$ 
A

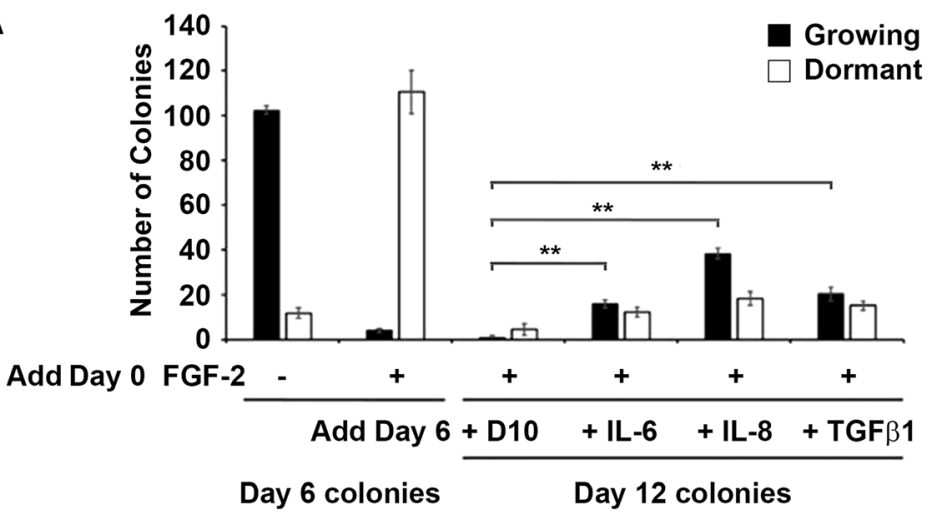

B

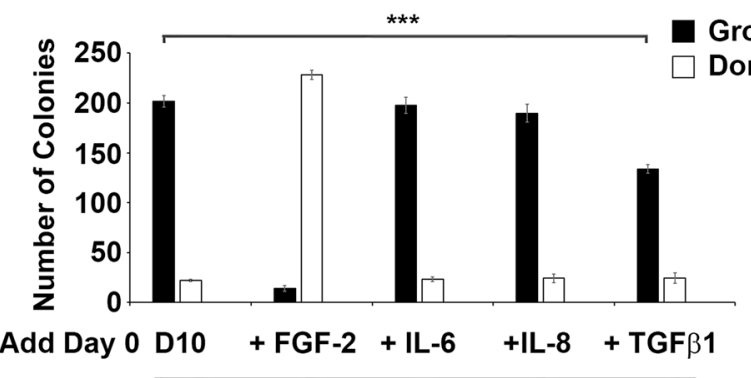

Growing

Dormant

Day 6 colonies

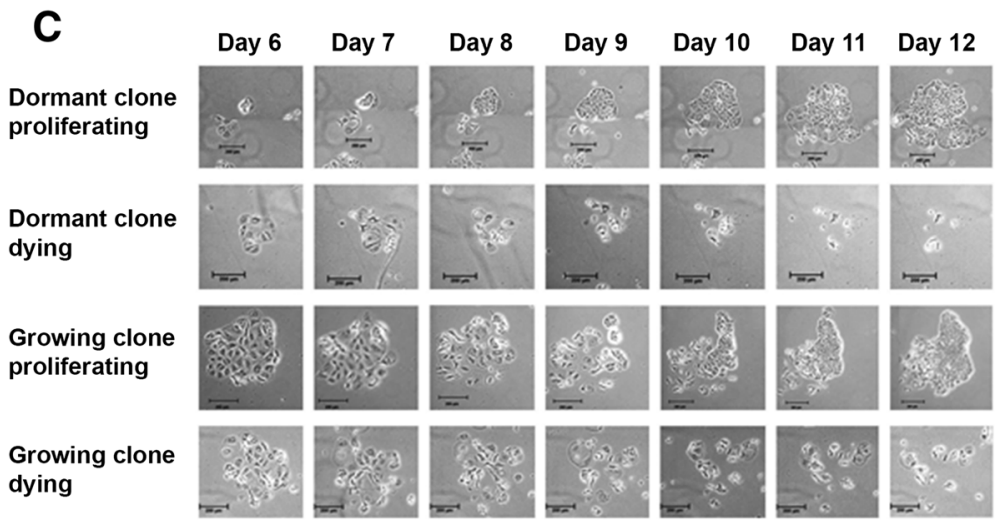

Fig. 1 Exogenous recombinant human IL-6, IL-8 and TGF $\beta 1$ induce reactivation of dormant breast cancer colonies but do not promote growth of growing colonies. a Cytokines induce regrowth of dormant colonies. One thousand MCF-7 cells were incubated in fibronectin-coated wells with FGF-2 for 6 days, followed by addition of recombinant human IL-6, IL-8 and TGF $\beta 1$ on day 6 and incubation for an additional 6 days, as described. Cells were stained with $0.1 \%$ crystal violet and growing and dormant colonies were counted on day 6 and 12. b Cytokines do not promote the growth of growing colonies. MCF-7 cells were incubated in fibronectin-coated wells with FGF-2 or recombinant human IL-6, IL-8 or TGF $\beta 1$, as described. Cells were stained with $0.1 \%$ crystal violet and growing and dormant colonies were counted on day 6. c Time lapse photography demonstrating regrowth potential of dormant clones. Photographs demonstrate growth expansion or degradation of both dormant and growing colonies. MCF cells were incubated on fibronectin-coated plates without and with FGF-2 for six days, followed by an additional 6 day incubation with fresh DMEM/10\% FCS without or with rhIL-6, IL-8 and TGF $\beta 1$, as described. Time-lapse microscopic images of the same individual colonies in the same fields were obtained once daily for these six days. Size markers are $200 \mu \mathrm{M}$

(Fig. 5a and b) and 24 and $48 \mathrm{~h}$ incubations with ICI 182780 at or above $10^{-8} \mathrm{M}$ (Fig. 5e and f) consistently induced secretion of IL-6 and IL-8 by murine stroma after $24 \mathrm{~h}$. Induction of hypoxia by poisoning the mitochondrial electron transport chain with CDDP for one hour did not induce secretion of IL-6 or IL-8 and, in fact, had the opposite effect (Fig. 5c and d). Injury to murine stroma also caused activation of the TGF $\beta$ signaling, as demonstrated by phosphorylation of SMAD-2 and SMAD-3 and estrogen deprivation induced activation of TNF- $\alpha$ (Fig. 6). As a result of these studies, we proceeded to conduct co-cultivation experiments with murine stroma. 


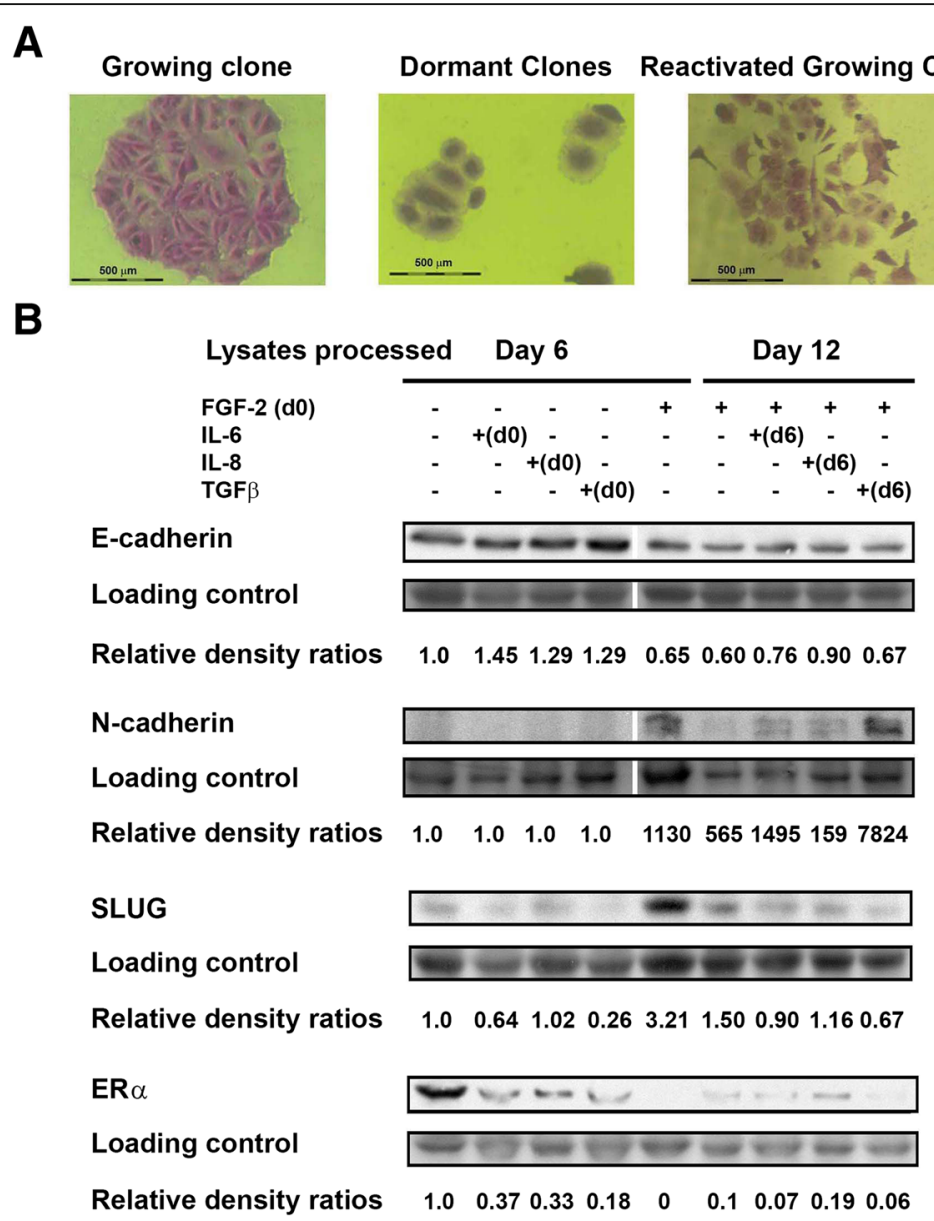

Fig. 2 Dormant and reactivated dormant breast cancer colonies exhibit characteristics of an epithelial to mesenchymal transition. a Morphological changes from epithelial (left) to a spindle like (right) morphology were observed between growing MCF-7 colonies and reactivated dormant cells. Colonies were photographed at 40X magnification. b Western blots performed with lysates from MCF-7 cells incubated with or without FGF-2 in tissue culture for 6 days and dormant cells incubated with rhIL-6, IL-8 and TGF $\beta 1$ for an additional 6 days on fibronectin at clonogenic density. Blots were stained with antibodies to human E-cadherin, N-cadherin, SLUG, and ERa. Coomassie blue-stained gels were used as loading controls. Relative band intensity ratios to those of the corresponding loading control were determined

Stromal injury results in increased growth of co-cultured breast cancer colonies

Confluent murine stromal monolayers in quadruplicate wells on 24 well plates were treated with $\mathrm{H}_{2} \mathrm{O}_{2}$ or CCCP for an hour or with ICI 182780 for two days, as described above. The medium was replaced with $1 \mathrm{ml}$ DMEM/10\% FCS containing 1000 Vybrant CM-DiI fluorescent dye tracker-labeled MCF-7 cells and the plates were re-incubated for 6 days. On day 6 , colonies were counted and photographed. Figure $7 \mathrm{a}$ demonstrates the appearance of two types of colonies, ones that were flat and embedded in the 2-dimensional stroma monolayer consisting of several dozen cells and ones that were growing as three dimensional spheroids atop the monolayer. Embedded colonies on stroma injured with $\mathrm{H}_{2} \mathrm{O}_{2}$, CCCP or ICI 182780 were more frequent (Fig. 7b) after 6 days than colonies in control wells. The embedded colonies appeared to have dormant cells at the periphery but contained growing cells internally. It was apparent that cells internal to the colony escaped factors in mouse stroma sustaining human breast cancer cell dormancy. The frequency of the three dimensional spherules were not statistically different with stromal injury. These data suggest that the growth of embedded colonies was stromal injury-dependent but that of anchorage-independent spheroids was autonomous. Blocking experiments with anti-murine CXCL1/KC (IL-8) antibodies did not prevent increased numbers of the embedded 2-D colonies or the 3-D spherules. Blocking of IL-8 was selected because murine IL-8 binds human IL-8 receptors while murine IL-6 does not. Clearly, other factors from injured stroma also contributed to promotion of growth.

\section{Co-cultivation of stroma with MCF-7 cells induces secretion of IL-6 and IL-8}

We tested the hypothesis that breast cancer cells induced to proliferate by cytokines secreted by injured 

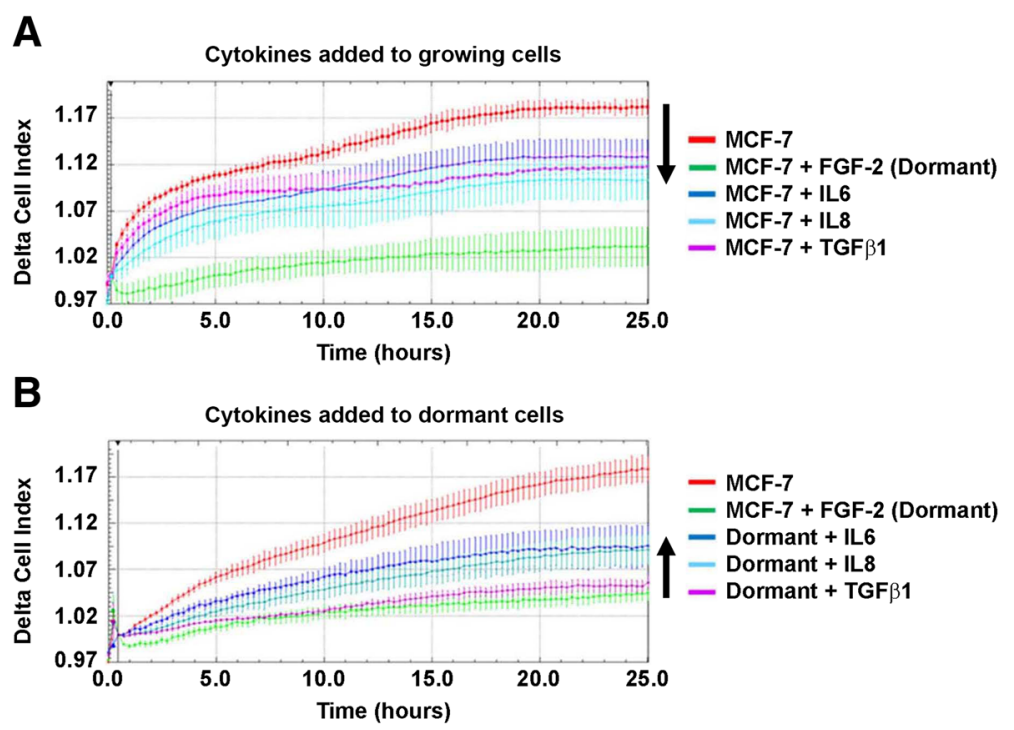

Fig. 3 Inflammatory cytokines have opposite effects on the migratory properties of growing and dormant cells. a Cytokines decrease the motility of growing cells. Fifty thousand MCF-7 cells were incubated on fibronectin-coated $10 \mathrm{~cm}$ plates. The following day (day 0), DMEM/10\% FCS without or with recombinant human FGF-2, IL-6, IL-8 or TGF $\beta 1$ were added to the plates to achieve a final concentration of $10 \mathrm{ng} / \mathrm{ml}$. On day 6 , cells were detached into single cell suspension by trypsin and 100,000 cells were added to the CIM-plate wells. Arrow indicates decreased motility of cytokine-treated growing cells compared to that of growing cells. $\mathbf{b}$ Cytokines increase the motility of dormant cells. Fifty thousand MCF-7 cells were incubated on fibronectin-coated $10 \mathrm{~cm}$ plates and DMEM/10\% FCS and FGF-2 was added the following day. Six days later, DMEM/10\% FCS without or with recombinant human IL-6, IL-8 or TGF $\beta 1$ were added to the cultures. On day 12, cells were detached into single cell suspension by trypsin and 100,000 cells were added to each well of the CIM-plate. Trypsin-dispersed day 6 dormant cells were used as negative controls. Arrow indicates increased motility of cytokine-treated dormant cells compared to that of dormant cells. Results represent the average of triplicate wells

stroma may in turn feedback stimulate the stroma to sustain the secretory senescence initiated by injury. We co-incubated breast cancer cells with murine stroma and measured cytokine secretion in the conditioned media. Figure 8 demonstrates that co-incubation of breast cancer cells with murine stroma induced significant secretion of IL-6 and IL-8 into the conditioned medium in a dose dependent manner up to a maximum limit which was significantly higher than that achieved by $\mathrm{H}_{2} \mathrm{O}_{2}$ injury, used as a positive control. Similar data were obtained with human stroma. Control experiments measuring conditioned medium from chemically-injured murine stroma, from human breast cancer cells and from the two cell types cultured together using both murine and human cytokine antibodies demonstrates that IL- 6 and IL- 8 were produced almost entirely by the stromal cells when co-cultured with breast cancer cells (Fig. 9), suggesting that cancer cells induce further feedback injury to the stroma as they proliferate.

\section{Discussion}

This study adds further clarity to our in vitro dormancy model of estrogen sensitive human breast cancer cell lines, as illustrated in Fig. 10. It demonstrates that injury to bone marrow stroma can induce the secretion of inflammatory cytokines IL- 6 and IL- 8 and activate TGF $\beta 1$ signaling. These cytokines and growth factor, in turn, can promote dormant ER+ breast cancer cells in our in vitro model to change their phenotype to a mesenchymal appearance and begin to proliferate and migrate. Based on the differences in appearance and behavior between dormant and reawakened cells, the data would suggest that these cytokines and TGF $\beta 1$ induced an EMT in these cells. However, our data demonstrated that, surprisingly, the EMT program was already activated in the dormant cells, despite their characteristic appearance as very large epithelioid cells with high cytoplasm to nucleus ratios and round, non-polar shapes with omnidirectional focal complex activation and cortical actin redistribution [34, 37]. Interestingly, ER $\alpha$ was also downregulated in dormant cells or by exogenous cytokines and was further diminished in reactivated dormant cells that acquired the mesenchymal phenotype. This finding may have significant implications in the standard of care use of estrogen binding or synthetic inhibitors in the adjuvant setting of ER+ breast cancer.

EMT events are described as collectively necessary for the acquisition of an invasive phenotype by differentiated epithelial cells in most cases, rendering the cell capable of metastasis. These include an initial dissolution of epithelial intercellular junctions, loss of the characteristic epithelial apical-basal polarity, acquisition of front-rear 
A
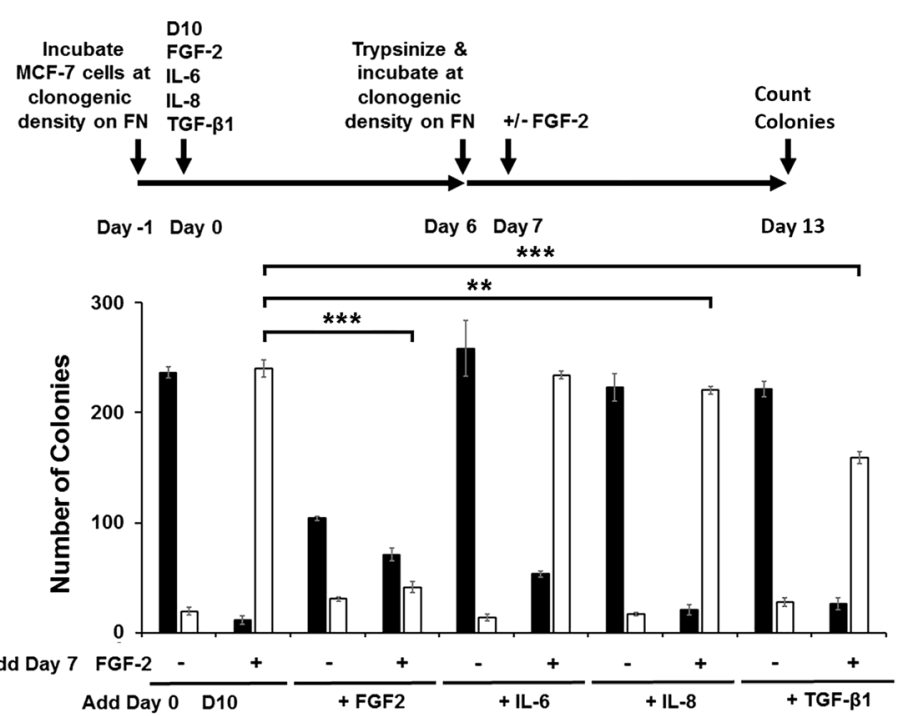

Growing

$\square$ Dormant

B

Day 13 colonies
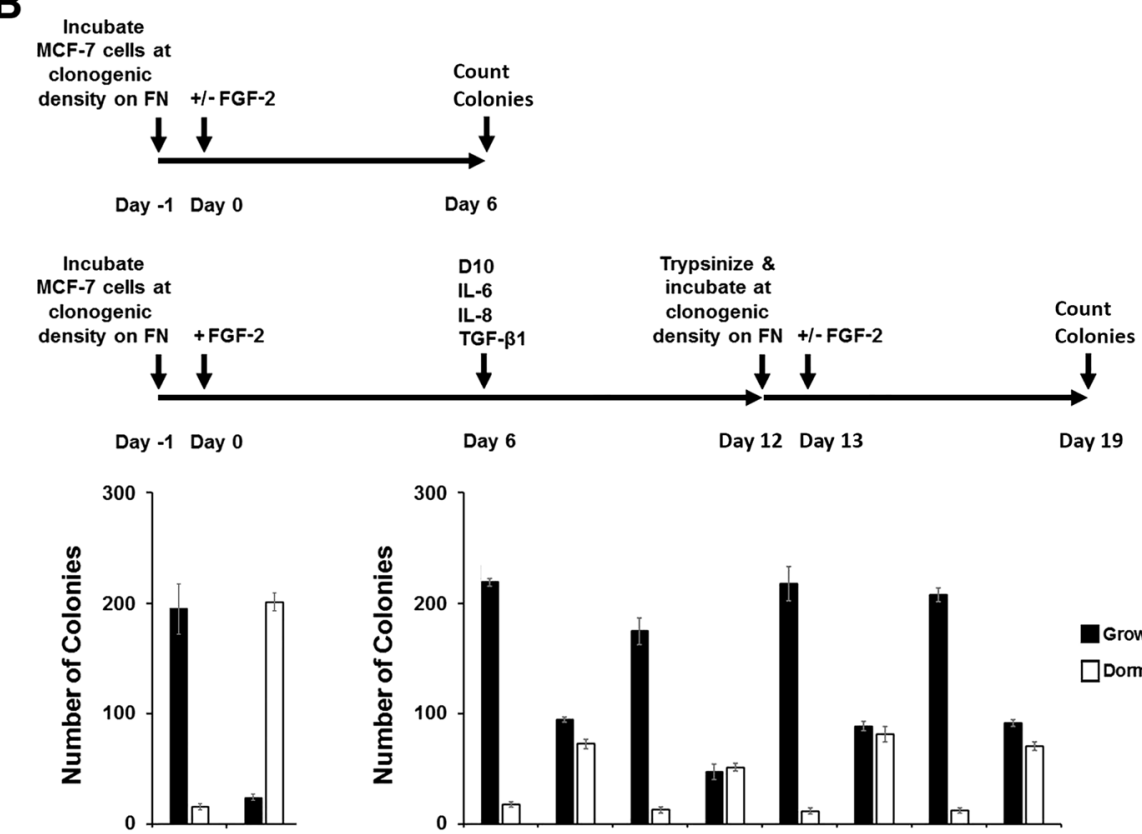

Add Day 0 FGF-2

+ Add Day 0 FGF-2 + Add Day 13 FGF-2

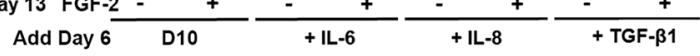

Day 6 colonies

Day 19 colonies

Fig. 4 (See legend on next page.) 
(See figure on previous page.)

Fig. 4 Dormant and reactivated dormant colonies have an impaired ability to re-enter the dormant state. a A total of 50,000 MCF-7 cells were incubated on fibronectin-coated $10 \mathrm{~cm}$ plates. The following day (day 0) DMEM/10\% FCS without or with recombinant human FGF-2, IL-6, IL-8 or TGF $\beta 1$ were added to the wells to achieve a final concentration of $10 \mathrm{ng} / \mathrm{ml}$. On day 6 , cells were detached into single cell suspension by trypsin and 1000 cells/well were incubated in quadruplicate on 24 well fibronectin-coated plates. On day 7 DMEM/10\% FCS without or with FGF-2 at a final concentration of $10 \mathrm{ng} / \mathrm{ml}$ was added to the cultures. On day 13 , wells were stained with $0.1 \%$ crystal violet and growing and dormant colonies were counted. b MCF-7 cells were incubated on fibronectin-coated $10 \mathrm{~cm}$ plates. The following day (day 0) DMEM/10\% FCS with FGF-2 was added to the wells to achieve a final concentration of $10 \mathrm{ng} / \mathrm{ml}$. On day 6, DMEM/10\% FCS without or with recombinant human IL-6, IL-8 or TGF- $\beta 1$ was added to the wells to achieve a final concentration of $10 \mathrm{ng} / \mathrm{ml}$. On day 12, cells were detached into single cell suspension by trypsin and 1000 cells/well were incubated in quadruplicate on 24 well fibronectin-coated plates. On day 13, DMEM/10\% FCS without or with FGF-2 at a final concentration of 10 ng/ $\mathrm{ml}$ was added to the cultures. On day 19 , wells were stained with $0.1 \%$ crystal violet and growing and dormant colonies were counted. In a control experiment, MCF-7 cells were incubated on fibronectin-coated 24-well plates at 1000 cells/well. DMEM/10\% FCS without or with FGF-2 at a final concentration of $10 \mathrm{ng} / \mathrm{ml}$ was added the next day. Six days later, wells were stained with $0.1 \% \mathrm{crystal}$ violet and growing and dormant colonies were counted. Results represent the average of quadruplicate wells. Error bars: Standard Deviation. ${ }^{*} p<0.05,{ }^{* *} p<0.01{ }^{* * *} p<0.001$

A

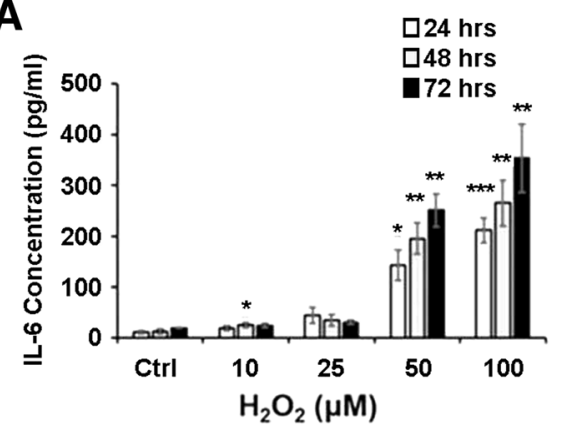

C

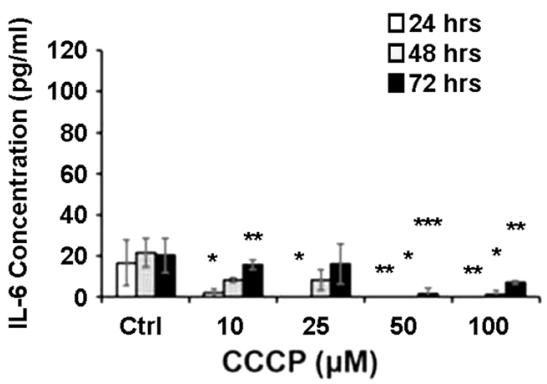

E

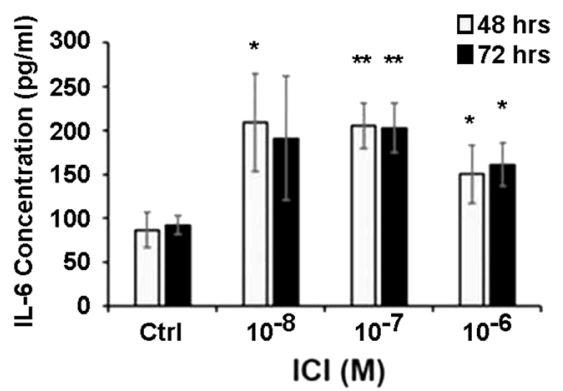

B

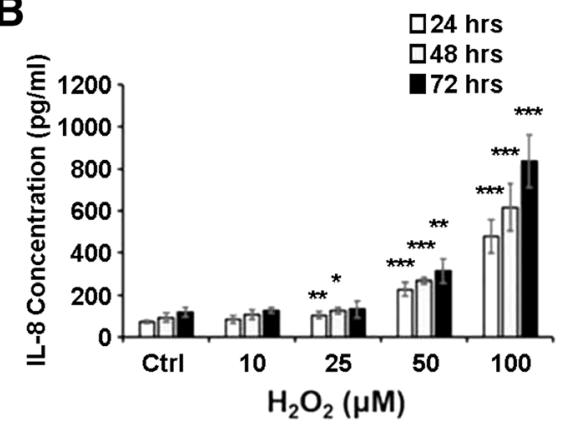

D

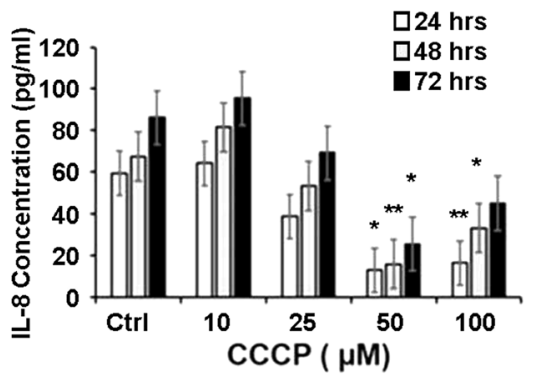

$\mathbf{F}$

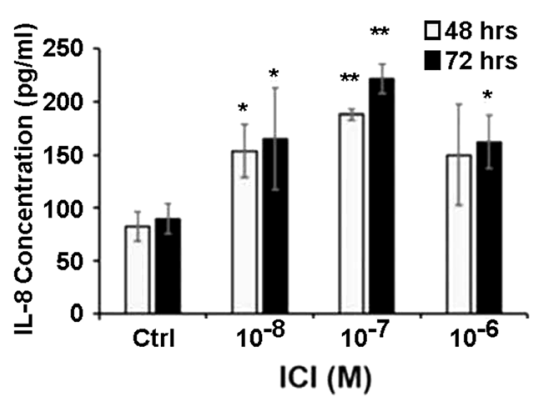

Fig. 5 Oxidative stress and estrogen deprivation promote higher production of IL-6 and IL-8 secretion in murine bone marrow stromal cells. ELISA assays demonstrated significantly higher levels of production of IL-6 (a and $\mathbf{e}$ ) and IL-8 (b and $\mathbf{f}$ ) in the conditioned medium from murine stromal layers treated with $\mathrm{H}_{2} \mathrm{O}_{2}$ and ICI 182780. Induction of hypoxia by CCCP did not cause similar effects (c and $\mathbf{d}$ ). Near confluent stromal monolayers cultured in 24-well plates were treated with $\mathrm{H}_{2} \mathrm{O}_{2}$ and CCCP in serum-free medium for $1 \mathrm{~h}$, washed once and incubated in DMEM/10\%FCS medium. Supernatant samples were collected at 24,48 and $72 \mathrm{~h}$. Confluent stromal monolayers cultured in 24-well plates were treated with ICI 182780 in medium without phenol-red for $48 \mathrm{~h}$ and $72 \mathrm{~h}$, washed once and incubated with DMEM/10\%FCS medium. The IL- 6 and IL-8 levels were determined using murine IL-6 and CXCL1/KC ELISA kit according to manufacturer's instructions. Error bars: Standard Deviation. ${ }^{*} p<0.05,{ }^{* *} p<0.01{ }^{* * *} p<0.001$ 


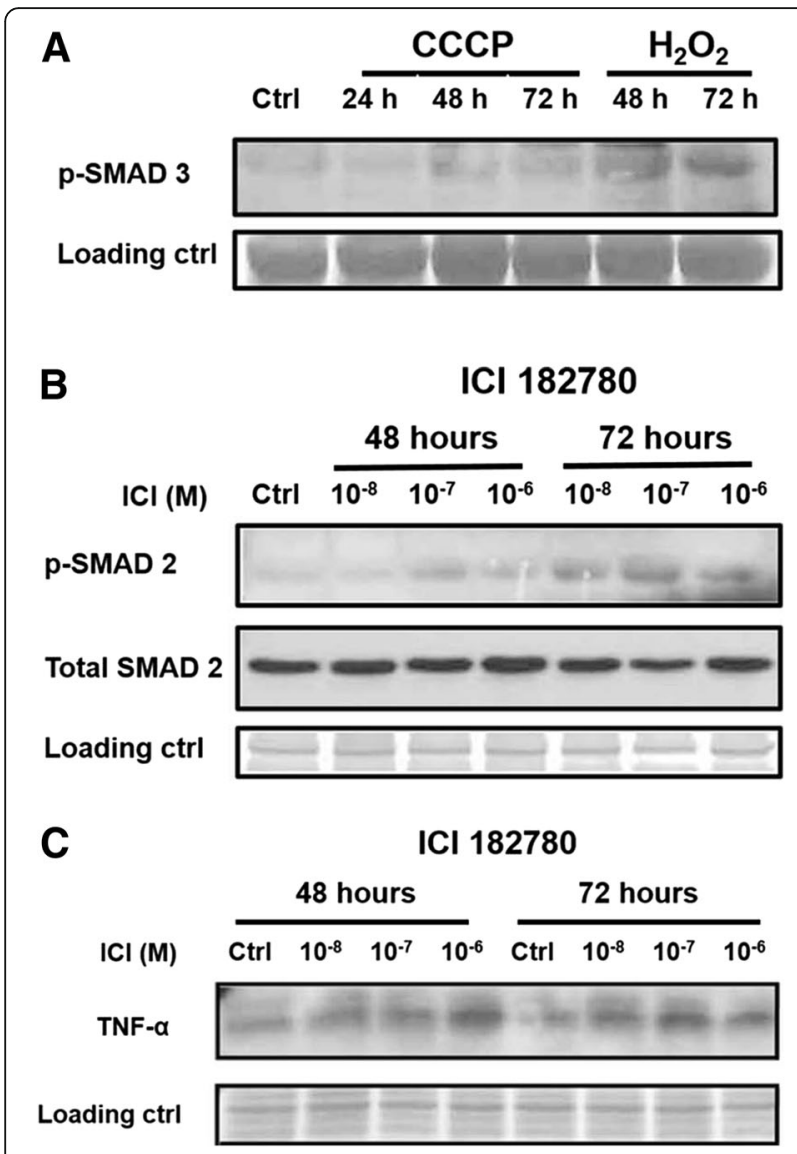

Fig. 6 Oxidative stress, hypoxia and estrogen deprivation induces activation of TGF $\beta$ and TNFa signaling pathway. Western blots for (a). phospho-SMAD-3 of murine stromal cells treated with $\mathrm{H}_{2} \mathrm{O}_{2}$ and CCCP, and (b). phospho-SMAD-2 and (c). TNFa of mouse stromal cells treated with ICI 182780. Nearly confluent mouse stromal monolayers maintained in $10 \mathrm{~cm}$ plastic dishes were treated with $100 \mu \mathrm{M}$ of $\mathrm{H}_{2} \mathrm{O}_{2}$ and CCCP for one hour, washed with PBS and incubated in DMEM/10\%FCS for 24, 48, or $72 \mathrm{~h}$. Mouse stromal monolayers were also treated with ICI 182780 at different concentrations $\left(10^{-8}, 10^{-7}\right.$ and $\left.10^{-6} \mathrm{M}\right)$ for 48 and $72 \mathrm{~h}$. Cells were lysed in modified RIPA buffer and analyzed by SDS-PAGE with antibody to mouse phospho-SMAD-2, total SMAD-2, phospho-SMAD-3 and TNFa

polarity and reorganization of cytoskeletal architecture with formation of stress fibers [49]. The changes are dependent on the reprogramming of gene expression from a characteristic epithelial expression pattern that includes synthesis of E-cadherin to a characteristic mesenchymal program. The latter includes synthesis of transcription factors Snail1 or Snail2/Slug, ZEB1 or ZEB2 and Twist and a switch to expression of N-cadherin. The mesenchymal program also entails a switch in the integrin repertoire, expression of matrix metalloproteases that enable invasive behavior [49-51] and activation of small GTPase signaling by guanine nucleotide exchange factors (GEFs) responsible for the observed cytoskeletal changes $[52,53]$. In other systems, it is well

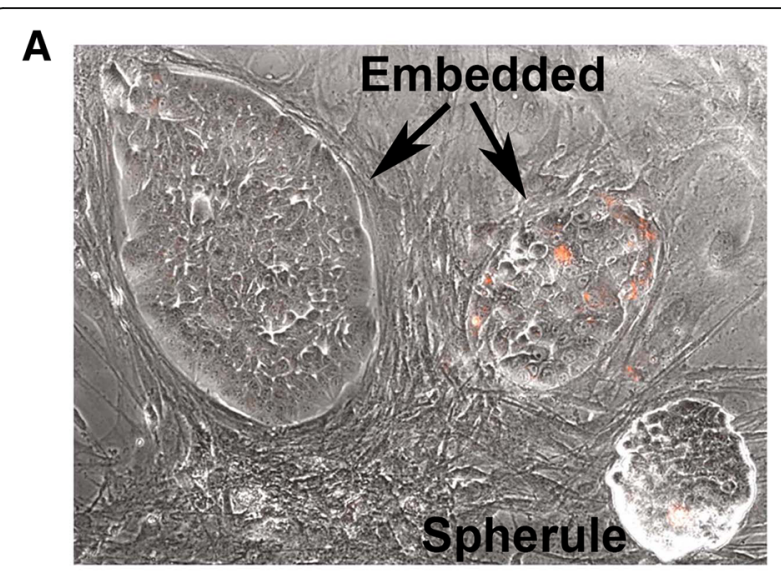

B

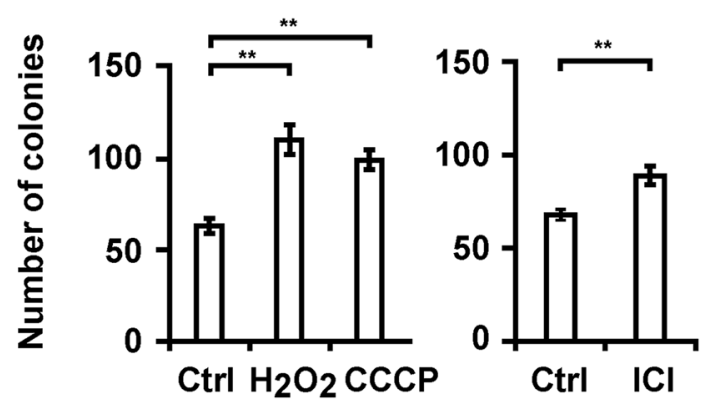

Fig. 7 Stromal oxidation-, hypoxia-, and estrogen deprivationinduced injury permit outgrowth of co-cultivated breast cancer colonies. a Photomicrograph (100x) of two embedded breast cancer cell colonies (Embedded) and a non-adherent breast cancer cell spherule (Spherule) on murine bone marrow stroma monolayers after six days of incubation. Breast cancer cells were labeled with Vybrant CM-Dil prior to co-culture. $\mathbf{b}$ The number of embedded colonies after six days of co-incubation with stroma treated with control DMEM/10\% FCS, DMEM/10\% FCS with $\mathrm{H}_{2} \mathrm{O}_{2}\left(5 \times 10^{-5} \mathrm{M}\right)$ and CCCP $\left(5 \times 10^{-5} \mathrm{M}\right)$ or stroma treated with ICI $182780\left(10^{-7} \mathrm{M}\right)$ in phenol red-free DMEM/10\% FCS or phenol-red-free control. Error bars: Standard Deviation. ${ }^{* *} p<0.01$

documented that FGF-2 and other ligands of receptor tyrosine kinases induce EMT $[54,55]$.

In our studies of the dormancy phenotype, we demonstrated that in fact, cells induced into a dormant state by FGF-2 already underwent many of these mesenchymal events, including re-expression of integrins lost with de-differentiation [34] and activation of MAPK [36], p38 [36] and PI3K/protein kinase B (Akt)/Glycogen synthase kinase-3b (GSK3b) [34, 36], Our studies also demonstrated that exogenous FGF-2 induces matrix metalloproteases in breast cancer cells [56]. However, contrary to these events, FGF-2 inhibits proliferation of ER+ breast cancer cells by activation of cell cycle inhibitors $\mathrm{p} 21^{\mathrm{WAF} 1 / \mathrm{Cip} 1}, \mathrm{p} 27^{\mathrm{KIP} 1}$ and $\mathrm{p} 15^{\mathrm{INK} 4 \mathrm{~B}}$ resulting in dephosphorylation and activation of retinoblastoma protein $(\mathrm{Rb})$ and cell cycle arrest [35, 48]. Our model demonstrated that dormancy is sustained through omnidirectional activation of focal adhesion complexes, which 

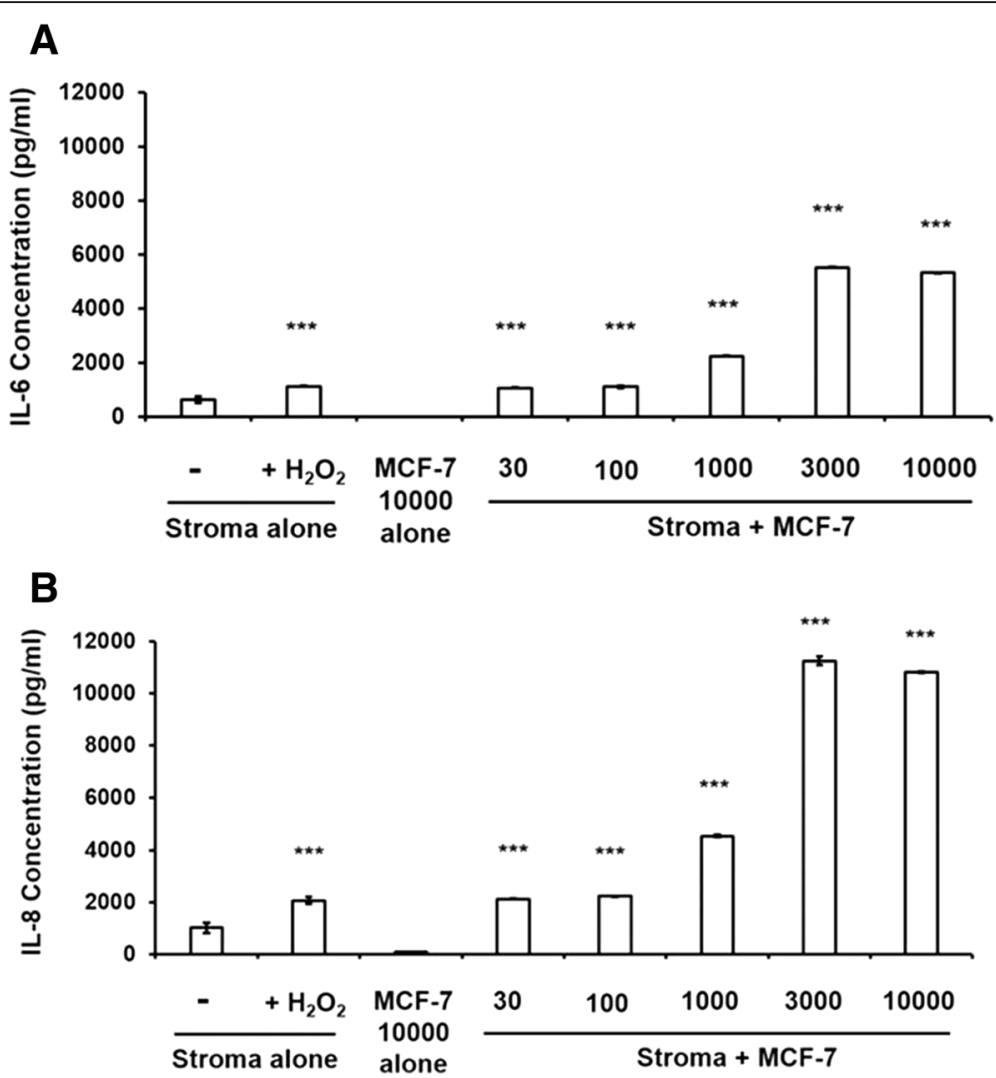

Fig. 8 Co-cultivation of murine bone marrow stromal cells with MCF-7 breast cancer cells induces increases in secretion of IL-6 and IL-8. Confluent stroma were treated with $\mathrm{H}_{2} \mathrm{O}_{2} 100 \mu \mathrm{M}$ for an hour, washed once with PBS, medium was changed to DMEM/5\%FCS and conditioned medium was sampled for injury-induced IL-6 and IL-8 production as positive controls. Simultaneously, medium on uninjured stroma in triplicate wells were changed to DMEM/5\%FCS containing variable numbers of MCF-7 cells and incubated for $48 \mathrm{~h}$. Conditioned medium samples were collected $48 \mathrm{~h}$ after incubation and (a). IL-6 and (b). IL-8 concentrations were determined using murine IL- 6 and CXCL1/KC ELISA kits, respectively, according to manufacturer's instructions. Error bars: Standard Deviations. ${ }^{*} p<0.05,{ }^{* *} p<0.01{ }^{* * *} p<0.001$

include Y397-phosphorylation of focal adhesion kinase (FAK) and the inactivation of RhoA through membrane localization of the Rho GAP GRAF [37] (Fig. 10). GRAF binds the C-terminal SH3 domain of the membrane localized FAK [57] and blocks RhoA-mediated stress fiber formation [58], resulting in rearrangement of F-actin to a cortical distribution [37]. These events depend on dual signaling through FGF-2 and fibronectin-mediated outside-in activation of integrin $\alpha 5 \beta 1$ [37]. Hence, the activation of the mesenchymal signaling and gene expression pattern in dormant cells is suppressed by the inactivation of RhoA, sustained cortical actin redistribution and focal complex formation, events that collectively maintain the dormant phenotype with a characteristic dormant appearance and impaired motility (Fig. 10). When the dormancy-initiating signaling through FGF-2 and integrin $\alpha 5 \beta 1$ is disrupted however, the EMT phenotype becomes evident and the cells take on a mesenchymal appearance, begin to proliferate and become motile. IL- 6 , IL- 8 and TGF $\beta 1$ accentuate the proliferative and motile behavior.
Evidence from other systems demonstrates that the inflammatory cytokines IL- 6 and IL- 8 promote cancer progression. IL-6 and IL-8 can promote the growth of epithelial ovarian cancer cells [59]. IL-8 affects androgen independence [60] and IL-6 induces androgen receptor activation during prostate cancer cell progression [61]. The IL-8-induced androgen-independent growth and migration was shown to be mediated through the oncogene cellular-Src kinase (c-Src) and FAK [62]. These data are not inconsistent with our observations that both IL-6 and IL- 8 decrease the expression of ER $\alpha$ in our growing MCF-7 cells. The pro-malignant effects of IL- 6 and IL- 8 have been reported to be mediated by signaling through several pathways, including through vascular endothelial growth factor (VEGF) [63] through PI3K/ Akt [64], by an autocrine loop through epidermal growth factor receptor (EGFR) transactivation mediated by extracellular signal-regulated kinase (ERK) [65], through the gp130 receptor and STAT3 [66, 67], and by p38 MAPK [68]. IL-6 inhibits EGFR promoter methylation, decreasing sensitivity to therapeutic intervention 
A

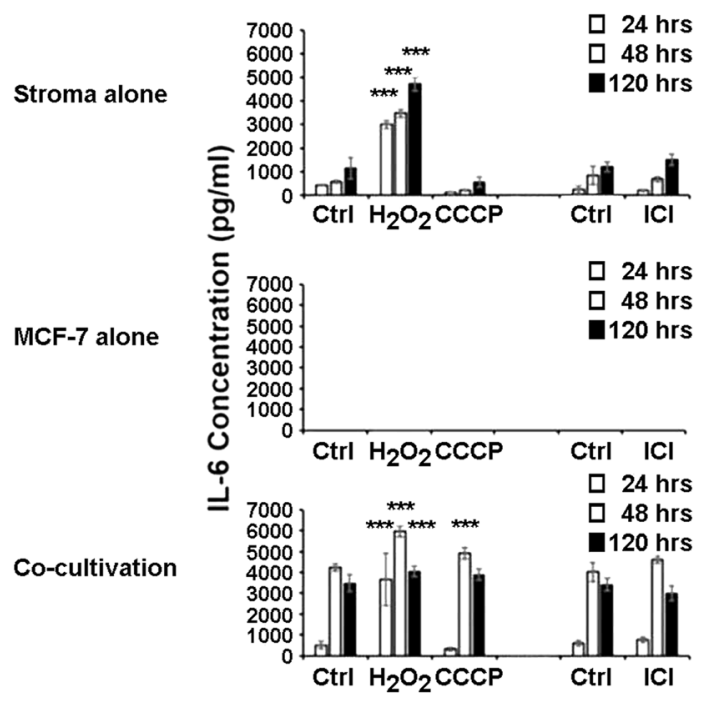

B

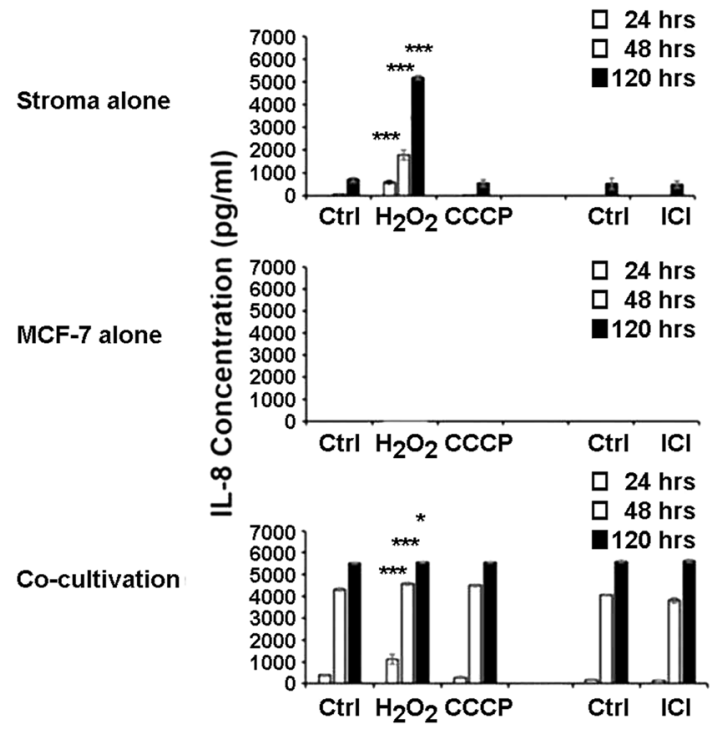

Anti-Human IL-6 antibody

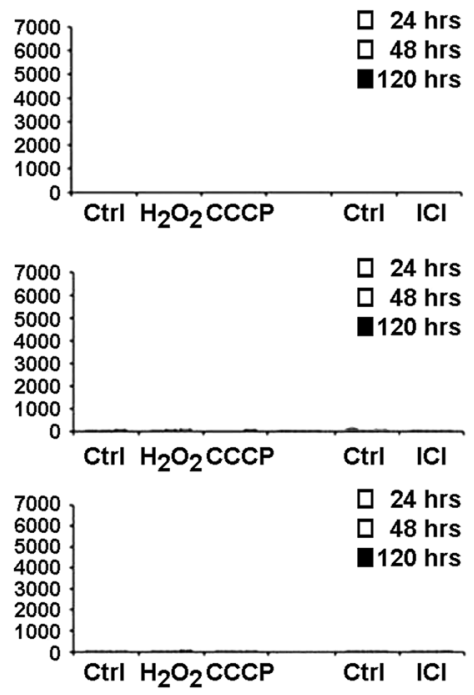

Anti-Human IL-8 antibody

7000
6000
5000
4000
3000
2000
1000
0

Fig. 9 Bone marrow stromal cells are the primary contributors of production of IL-6 and IL-8 in co-cultivation with MCF-7 breast cancer cells. ELISA assays demonstrated significantly higher levels of production of murine (a). IL-6 and (b). IL-8. MCF-7 breast cancer cells (1000 cells/well) were seeded on human fibronectin coated 24-well plate. On day 3, cells were treated with $\mathrm{H}_{2} \mathrm{O}_{2}$ and CCCP for one hour in serum-free medium, and with $\mathrm{ICI}$ for 2 days in DMEM/10\%FCS medium without phenol-red, washed once and incubated in DMEM/10\%FCS. Confluent stromal monolayers were prepared from murine bone marrow stroma as before. At confluence, stromal monolayers were treated with $\mathrm{H}_{2} \mathrm{O}_{2}$ and $\mathrm{CCCP}$ for one hour and with $\mathrm{ICl}$ for 2 days, washed once and incubated in DMEM/10\%FCS medium. MCF-7 breast cancer cells (1000 cells/well) were co-incubated with control and $\mathrm{H}_{2} \mathrm{O}_{2} 50 \mu \mathrm{M}, \mathrm{CCCP} 50 \mu \mathrm{M}$ and ICl-treated stromal monolayers for 6 days. Supernatant samples were collected 24, 48 and $120 \mathrm{~h}$ and murine and human IL-6 and IL-8 levels in the supernatant were determined using murine and human IL-6 ELISA kit, and murine CXCL1/KC and human CXCL8/IL-8 ELISA kit according to the manufacturer's instructions. Error bars: Standard Deviation. ${ }^{*} p<0.05,{ }^{* *} p<0.01{ }^{* *} p<0.001$

with methylation inhibitors [69]. IL-6 may also induce relative chemotherapy resistance through Akt, myeloid leukemia cell differentiation protein-1 (Mcl-1) and TNF-related apoptosis-inducing ligand (TRAIL) [70-72] and modulation of B-cell lymphoma-2-associated X protein Long (BclXL) and (bcl-2-like protein 4) (BAX), [73].
IL-6 and IL-8 also enable the microenvironment to promote cancer progression by promoting migration and matrix metalloprotease (MMP) production in dermal fibroblasts [74], bone resorption and osteolytic metastases though cyclooxygenase-2 (Cox-2)/prostaglandin E2 (PGE2) [75, 76]. It is evident that these cytokines, as well 


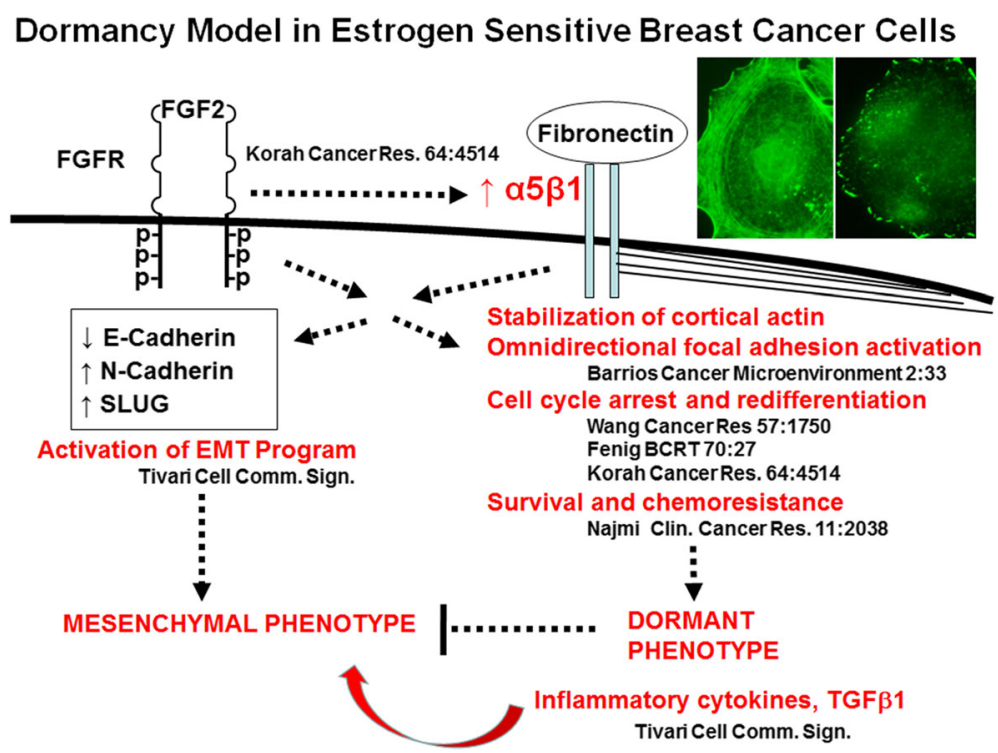

Fig. 10 Schematic of the in vitro FGF-2-initiated dormancy model of estrogen sensitive human breast cancer cells. According to the model, FGF-2 induces re-expression of integrin a5 $\beta 1$ and together with its fibronectin-binding, a cell dormancy phenotype through cell spreading, cortical redistribution of fibrillar actin and omnidirectional activation of FAK, cell cycle arrest, survival and chemoresistance. FGF-2 and a5 31 also induce activation of the EMT gene expression program which can lead to a mesenchymal phenotype, but the transition is repressed by the dormancy program. This repression is released by inflammatory cytokines and TGF $\beta 1$, outlined within this study. References are provided for events outlined. Phylloidin-stained (left) and anti-phospho-FAK-stained (right) dormant MCF-7 cells on fibronectin are displayed

as growth factors, activate different signal pathways, often depending on whether an epithelial or mesenchymal program is activated in a particular cell.

In contrast to the proliferative effects on dormant cells, rhIL-6 and rhIL-8 did not promote the growing colony forming potential of growing cells. This is also consistent with prior observations where IL- 6 undergoes transition from a growth inhibitor associated with neuroendocrine differentiation to a growth stimulator during prostate cancer cell progression [61]. We did observe, that, in fact, rhIL-6, rhIL-8 and rhTGF $\beta 1$ decreased the motility of growing epithelial cells (Fig. 3). This effect was associated with and potentially due to the increased expression of E-cadherin by incubation with these factors (Fig. 2).

rhTGF $\beta 1$ also had a dual effect on MCF-7 cells, depending on whether they were growing, in which case it inhibited the cells' potential to form growing colonies (Fig. 1b), or dormant with an activated EMT gene expression program, where it promoted their growing colony forming potential (Fig. 1a). This recapitulated the well-documented opposing effects of TGF $\beta 1$ on malignant mammary epithelial cells before and after EMT [77].

The mechanisms of TGF $\beta 1$ inhibitory effects on epithelial cells are mediated through activation of cdk inhibitors $\mathrm{p} 16^{\mathrm{INK} 4 \mathrm{~A}}, \mathrm{p} 15^{\mathrm{INK} 4 \mathrm{~B}}, \mathrm{p} 21^{\mathrm{WAF} 1 / \mathrm{Cip} 1}$, and/or $\mathrm{p} 27^{\mathrm{KIP} 1}$ and repression of c-Myc expression through downregulation of the Inhibitor of Differentiation/DNA binding 1 (ID1) induced by SMAD 3/4 [78, 79]. Under conditions of intense mitogenic stimulation, TGF $\beta 1$ triggers cytostasis or apoptosis, depending on the intensity of the proliferative signal $[80,81]$. In this context, we previously demonstrated that FGF-2 activated ERK in MCF-7 cells while simultaneously upregulating $\mathrm{p}^{\mathrm{WAF} 1 / \mathrm{Cip} 1}$ and $\mathrm{p} 27^{\mathrm{KIP} 1}$, resulting in G1 cell cycle arrest [82], and downregulated $\mathrm{Bcl} 2$ and upregulated BAX resulting in increased apoptosis [83]. In this setting, we previously demonstrated that the growth inhibitory effects of FGF-2 through $\mathrm{p} 21^{\mathrm{WAF} 1 / \mathrm{Cip} 1}$ and $\mathrm{p} 27^{\mathrm{KIP} 1}$ were mediated through TGF $\beta 1$ [48].

The tumor suppressive effects of TGF $\beta 1$ are lost in cells that have undergone EMT [49, 78]. Reasons include mutations in transforming growth factor beta receptor II (TGFßRII), discontinuing the induction or deletion of $\mathrm{p} 15^{\mathrm{INK} 4 \mathrm{~B}}, \mathrm{p} 16^{\mathrm{INK} 4 \mathrm{~A}}$ and ARF, promotion of ID1 and induction of c-Myc expression [78], and mutations in SMADs. TGF $\beta 1$ promotes EMT by a program dependent on SMAD-mediated transcriptional events that induce SNAIL, SLUG and TWIST [84] as well as SMAD-independent events that promote changes in the cytoskeleton and cell junctional complexes [85] through activation of RhoA [86, 87]. SMADs induce Ras signaling [88] and motility through human epidermal growth factor receptor-2 (Her2/neu) [89]. Signal pathways activated by TGF $\beta 1$ in the induction of EMT include the PI3K/Akt/mTOR pathway $[49,90]$, the ERK pathways [49].

Our data also demonstrate that ER+ breast cancer cells that have undergone activation of the mesenchymal program have a significantly diminished capacity to re-enter 
dormancy in response to FGF-2. Cells treated with FGF-2 on day 0, disbursed on day 6 and re-incubated with rhFGF-2 form dormant colonies very inefficiently. Parenthetically, we also found that cells treated with TGF $\beta 1$ on day 0 also have a decreased capacity to be induced into dormancy by incubation with FGF-2 on day 6 (Fig. 4a). It is clear that a change affects cells during the EMT program that renders them resistant to the ability of FGF-2 to induce cell cycle arrest and the dormancy program previously described $[34,36,37]$. It is possible that EMT may modulate FGF-2 receptor splice variants with mesenchymal transition [91], which may be needed for induction of dormancy. These hypotheses remain the subject of future investigations.

Some insight into the heterogeneity and stochastic nature of recurrence of ER+ breast cancer in the population was gleaned from the lack of reproducibility in the injury data we observed with human stroma. Since we are postulating that injury to stroma over a lifetime either by chemical injury or estrogen deprivation from menopause likely contributes to the random recurrence of dormant micrometastases in the marrow, the capacity of the bone marrow stroma to withstand insult among different patients may very well contribute to the randomness of recurrence. The lack of direct effect of a hypoxic pulse on induction of cytokine secretion was not unexpected. The bone marrow microenvironment is relatively hypoxic $[92,93]$ and thus cells are adapted to function normally under these conditions. Since aging stroma is most sensitive to injury, a logical corollary would suggest that stroma from young donors would be more resilient. The variable response to injury in stroma from normal volunteers could be explained by age as well as genetic variability. It was the primary reason we decided to conduct our co-cultivation studies with inbred athymic mice. A large number of normal volunteers of variable ages will be needed to investigate this question.

\section{Conclusions}

The main conclusions of the study are:

1. Phenotypically dormant ER+ breast cancer cells in our in vitro dormancy model already have activated EMT gene expression programs and downregulated ER $\alpha$.

2. Stromal inflammation reactivates the growth and motility of dormant ER+ breast cancer cells and induces a mesenchymal phenotype.

3. Reactivated growing cells feedback activate the secretion of inflammatory cytokines by stroma.

4. Reactivated cells have an impaired ability to re-enter dormancy.

The importance and relevance of these findings relate to the high rate of occurrence of dormant micrometastases in the bone marrow of women with early stage breast cancer. Half of women with ER+ localized breast cancer recur by 10 years after diagnosis, a usually fatal event. It is possible that downregulation of ER $\alpha$ in dormant cells may impact the effects of standard of care adjuvant therapy with estrogen blocking or synthetic inhibitors. These data demonstrate that injury to the bone marrow stroma through oxidation, hypoxia and estrogen deprivation induces reactivation of dormant micrometastases, mediated by stromal inflammatory responses. This establishes a rationale for investigating methods of preventing stromal inflammation as a potential mechanism of suppressing recurrence of micrometastases.

\section{Abbreviations}

Akt: PI3K/protein kinase B; ATCC: American Type Culture Collection; ATF: Activating transcription factor, a cyclic AMP-dependent transcription factor; ATRA: All-trans retinoic acid, a retinoic acid isoform; $A x l$ : $A X L$ receptor tyrosine kinase; $\mathrm{BAX}$ : BCl-2-like protein 4; BCIXL: B-cell lymphoma-2-associated $X$ protein-long; BMP: Bone morphogenic protein, a member of the transforming growth factor $\beta$ family; CCCP: Carbonyl-cyanide mchlorophenylhydrazzone; CDK: Cyclin dependent kinase; Cox2: Cyclooxygenase-2; c-SrC : Cellular c-Src kinase; CXCL1/KC: IL-8; DEC2: A basic helix-loop-helix transcription repressor involved in circadian rhythm; DMEM: Dulbecco's modifies Eagle's medium; EGFR: Epidermal growth factor receptor; EMT: Epithelial-mesenchymal transition; ER+: Estrogen receptor positive.; ERa: Estrogen receptor alpha; ERK: Extracellular signal-regulated kinase; F-actin: Fibrillar actin; FAK: Focal adhesion kinase; FBS: Fetal bovine serum; FGF-2: Fibroblast growth factor-2, basic fibroblast growth factor; GAP: Rho GTPase activating protein; GAS6: Growth arrest-specific 6; GEF: Guanine nucleotide exchange factor; GLUT-1: Glucose transporter-1; GRAF: GTPase Regulator Associated with the Focal Adhesion Kinase; GSK3b: Glycogen synthase kinase-3b; GTPase: Guanosine triphosphatase; $\mathrm{H}_{2} \mathrm{O}_{2}$ : Hydrogen peroxide; Her2/neu: Human epidermal growth factor receptor-2; HIF1: Hypoxia-inducible factor 1-alpha; HRP: Horseradish preroxidase; HSP70: Heat shock protein 70; HTB-22: Human MCF-7 Breast Adenocarcinoma; ICI 182780: Fulvestrant; ID1: Inhibitor of Differentiation/ DNA binding 1; IgG: Immunoglobulin G; IL: Interleukin; LIF: Leukemia inhibitory factor; LOXL2: Lysyl oxidase homolog 2; MAPK: Microtubuleassociated protein kinase; MCF-7: Michigan Cancer Foundation-7 breast cancer cells; Mcl-1: Myeloid leukemia cell differentiation protein-1; MMP: Matrix metalloprotease; mTOR: Mammalian target of rapamycin; NANOG: A homeobox transcription factor critically involved with self-renewal of undifferentiated embryonic stem cells; NDRG1: N-myc downregulated gene 1, a member of a protein family which belongs to the alpha/beta hydrolase superfamily; Notch3: Neurogenic locus notch homolog protein 3; NR2F1: Nuclear receptor subfamily 2 group $F$ member 1 , an orphan retinoic acid receptor; p21 ${ }^{\text {WAF1 }}$ : Cyclin dependent kinase interacting protein 1; p27 $7^{\text {kip1: }}$ Cyclin dependent kinase (CDK) inhibitor p27; p38: A mitogenactivated protein kinase gene activated by stress stimuli; PGE2: Prostaglandin E2; PI3K: Phosphoinositol-3 kinase; RANKL: Receptor activator of nuclear factor kappa-B ligand; RARß: Retinoic acid receptor beta; Rb: Retinoblastoma protein; RIPA: Radioimmunoprecipitation assay; rh: Recombinant human; Rheb: Ras homolog enriched in brain GTP-binding protein; RhoA: A member of the small GTPAse proteins regulating stress fibers; SDS-PAGE: Sodium dodecyl sulfate polyacrylamide gel electrophoresis; SLUG: Human embryonic zinc finger transcriptional repressor protein SNAI2 which downregulates expression of E-cadherin; SOCS3: Suppressor of cytokine signaling 3, a member of the STAT-induced STAT inhibitor family; SOX9: A transcription factor of the HMG-box class DNA-binding proteins; STAT3: Signal transducer and activator of transcription protein-3; TGF: Transforming growth factor- $\beta$, different members of the family include TGF $\beta 1$, TGF $\beta 2$ and bone morphogenic proteins (BMPs); TGF $\beta R$ II: Transforming growth factor beta receptor II; Tie2: An angiopoietin receptor encoded by the TEK gene; TNF: Tumor necrosis factor alpha; TRAIL: TNF-related apoptosis-inducing ligand;

UPA: Urokinase-type plasminogen activator; VCAM-1: Vascular cell adhesion molecule 1; VEGF: Vascular endothelial growth factor

Acknowledgements

We thank Dr. Paul Castellano for assistance with the time lapse studies. 


\section{Funding}

DOD: W81XWH-09-1-0119.

$\mathrm{NIH}:$ CA142537.

\section{Availability of data and materials}

Data sharing is not applicable to this article as no datasets were generated or analyzed during the current study.

\section{Authors' contributions}

ST performed most of the experiments in the manuscript, was involved in the planning and design of the study and writing of the manuscript. $\mathrm{HL}$ performed some of the experiments in the manuscript and was involved in the design of some of the experiments. TD performed some of the experiments in the manuscript and was involved in the design of some of the experiments. MS D L assisted with some of the experiments and was involved with the design and writing of the manuscript. RW was involved in conception, planning, design, interpretation and supervision of the studies and writing of the manuscript. All authors read and approved the final manuscript.

\section{Ethics approval and consent to participate}

Animal studies were approved by the New Jersey Medical School Institutional Animal Care and Use Committee.

Human bone marrow aspirates were obtained under a Rutgers University Institutional Review Board-approved protocol after informed consent.

\section{Consent for publication}

Not applicable.

\section{Competing interests}

The authors declare that they have no competing interests.

\section{Publisher's Note}

Springer Nature remains neutral with regard to jurisdictional claims in published maps and institutional affiliations.

\section{Author details}

'Department of Medicine, Rutgers New Jersey Medical School and Rutgers Cancer Institute of New Jersey, 205 South Orange Avenue, Cancer Center H1216, Newark, NJ 07103, USA. 'Department of Cell Biology and Molecular Medicine, Rutgers New Jersey Medical School and Rutgers Cancer Institute of New Jersey, Newark, NJ, USA.

Received: 27 April 2018 Accepted: 9 August 2018

Published online: 17 August 2018

\section{References}

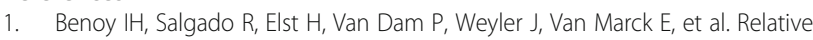
microvessel area of the primary tumour, and not lymph node status, predicts the presence of bone marrow micrometastases detected by reverse transcriptase polymerase chain reaction in patients with clinically non-metastatic breast cancer. Breast Cancer Res. 2005;7:R210-9.

2. Husemann $Y$, Geigl JB, Schubert F, Musiani $P$, Meyer M, Burghart $E$, et al. Systemic spread is an early step in breast cancer. Cancer Cell. 2008;13:58-68.

3. Sansone P, Ceccarelli C, Berishaj M, Chang Q, Rajasekhar VK, Perna F, et al. Self-renewal of CD133 ${ }^{\text {hi }}$ cells by IL6/Notch3 signalling regulates endocrine resistance in metastatic breast cancer. Nat Commun. 2016;7:10442-51.

4. Braun S, Vogl FD, Naume B, Janni W, Osborne MP, Coombes RC, et al. A pooled analysis of bone marrow micrometastasis in breast cancer. N Engl J Med. 2005;353:793-802.

5. Braun S, Kentenich C, Janni W, Hepp F, de Waal J, Willegroth F, et al. Lack of an effect of adjuvant chemotherapy on the elimination of single dormant tumor cells in bone marrow of high risk breast cancer patients. J Clin Onc. 2000;18:80-6.

6. Wieder R, Shafiq B, Adam N. African American race is an independent risk factor in survival from initially diagnosed localized breast cancer. J Cancer. 2016;7:1587-98.

7. Zhang XH, Giuliano M, Trivedi MV, Schiff R, Osborne CK. Metastasis dormancy in estrogen receptor-positive breast cancer. Clin Cancer Res. 2013;19:6389-97.
8. McBryan J, Fagan A, McCartan D, Bane FT, Vareslija D, Cocchiglia S, et al. Transcriptomic profiling of sequential tumors from breast cancer patients provides a global view of metastatic expression changes following endocrine therapy. Clin Cancer Res. 2015;21:5371-9.

9. Aguirre-Ghiso JA. Models, mechanisms and clinical evidence for cancer dormancy. Nat Rev Cancer. 2007;7:834-46.

10. Sosa MS, Bragado P, Aguirre-Ghiso JA. Mechanisms of disseminated cancer cell dormancy: an awakening field. Nat Rev Cancer. 2014;14:611-22.

11. Chery L, Lam HM, Coleman I, Lakely B, Coleman R, Larson S, et al. Characterization of single disseminated prostate cancer cells reveals tumor cell heterogeneity and identifies dormancy associated pathways. Oncotarget. 2014;5:9939-51.

12. Linde N, Casanova-Acebes M, Sosa MS, Mortha A, Rahman A, Farias E, et al. Macrophages orchestrate breast cancer early dissemination and metastasis. Nat Commun. 2018:9:21.

13. Fluegen $G$, Avivar-Valderas A, Wang Y, Padgen MR, Williams JK, Nobre AR, et al. Phenotypic heterogeneity of disseminated tumour cells is preset by primary tumour hypoxic microenvironments. Nat Cell Biol. 2017;19:120-32.

14. Mendez-Ferrer S, Michurina TV, Ferraro F, Mazloom AR, Macarthur BD, Lira $\mathrm{SA}$, et al. Mesenchymal and haematopoietic stem cells form a unique bone marrow niche. Nature. 2010:466:829-34.

15. Yu C, Shiozawa Y, Taichman RS, McCauley LK, Pienta K, Keller E. Prostate cancer and parasitism of the bone hematopoietic stem cell niche. Crit Rev Eukaryot Gene Expr. 2012;22:131-48.

16. Ghajar CM. Metastasis prevention by targeting the dormant niche. Nat Rev Cancer. 2015;15:238-47.

17. Linde N, Fluegen G, Aguirre-Ghiso JA. The relationship between dormant cancer cells and their microenvironment. Adv Cancer Res. 2016;132:45-71.

18. Johnson RW, Finger EC, Olcina MM, Vilalta M, Aguilera T, Miao Y, et al. Induction of LIFR confers a dormancy phenotype in breast cancer cells disseminated to the bone marrow. Nat Cell Biol. 2016;18:1078-89.

19. Yumoto K, Eber MR, Wang J, Cackowski FC, Decker AM, Lee E, et al. Axl is required for TGF-beta2-induced dormancy of prostate cancer cells in the bone marrow. Sci Rep. 2016;6:36520.

20. Mishra A, Wang J, Shiozawa Y, McGee S, Kim J, Jung Y, et al. Hypoxia stabilizes GAS6/Axl signaling in metastatic prostate cancer. Molecular Cancer Research: MCR. 2012;10:703-12.

21. Sosa MS, Parikh F, Maia AG, Estrada Y, Bosch A, Bragado P, et al. NR2F1 controls tumour cell dormancy via SOX9- and RARb-driven quiescence programmes. Nat Commun. 2015;6:6170.

22. Bragado P, Estrada Y, Parikh F, Krause S, Capobianco C, Farina HG, et al. TGFb2 dictates disseminated tumour cell fate in target organs through TGF-bRlll and p38a/b signalling. Nat Cell Biol. 2013;15:1351-61.

23. Schewe DM, Aguirre-Ghiso JA. ATF6alpha-Rheb-mTOR signaling promotes survival of dormant tumor cells in vivo. ProcNatl Acad Sci USA. 2008;105: 10519-24.

24. Aguirre Ghiso JA, Kovalski K. Ossowski L. Tumor dormancy induced by downregulation of urokinase receptor in human carcinoma involves integrin and MAPK signaling. J Cell Biol 1999:147:89-104.

25. Aguirre-Ghiso JA, Liu D, Mignatti A, Kovalski K, Ossowski L. Urokinase receptor and fibronectin regulate the ERK(MAPK) to p38(MAPK) activity ratios that determine carcinoma cell proliferation or dormancy in vivo. Mol Biol Cell. 2001;12:863-79.

26. Kobayashi A, Okuda H, Xing F, Pandey PR, Watabe M, Hirota S, et al. Bone morphogenetic protein 7 in dormancy and metastasis of prostate cancer stem-like cells in bone. J Exp Med. 2011;208:2641-55.

27. Ghajar $\mathrm{CM}$, Peinado H, Mori H, Matei IR, Evason KJ, Brazier $\mathrm{H}$, et al. The perivascular niche regulates breast tumour dormancy. Nat Cell Biol. 2013;15:807-17.

28. Han HH, Kim BG, Lee JH, Kang S, Kim JE, Cho NH. Angiopoietin-2 promotes ER+ breast cancer cell survival in bone marrow niche. Endocr Relat Cancer. 2016;23:609-23.

29. Lawson MA, McDonald MM, Kovacic N, Hua Khoo W, Terry RL, Down J, et al. Osteoclasts control reactivation of dormant myeloma cells by remodelling the endosteal niche. Nat Commun. 2015;6:8983.

30. Lu X, Mu E, Wei Y, Riethdorf S, Yang Q, Yuan M, et al. VCAM-1 promotes osteolytic expansion of indolent bone micrometastasis of breast cancer by engaging a4 $\beta 1$-positive osteoclast progenitors. Cancer Cell. 2011;20:701-14.

31. Barkan D, El touny LH, Michalowski AM, Smith JA, Chu I, Davis AS, Webster JD, Hoover S, Simpson RM, Gauldie J, Green JE. Metastatic growth from dormant cells induced by a col---enriched fibrotic environment cancer research. Cancer Res. 2010;70:5706-16. 
32. Weidenfeld K, Schif-Zuck S, Abu-Tayeh H, Kang K, Kessler O, Weissmann M, et al. Dormant tumor cells expressing LOXL2 acquire a stem-like phenotype mediating their transition to proliferative growth. Oncotarget. 2016;7:71362-77.

33. Barkan D, Kleinman H, Simmons JL, Asmussen H, Kamaraju AK, Hoenorhoff $\mathrm{MJ}$, et al. Inhibition of metastatic outgrowth from single dormant tumor cells by targeting the cytoskeleton. Cancer Res. 2008;68:6241-50.

34. Korah $\mathrm{R}$, Boots $M$, Wieder R. Integrin a5 31 promotes survival of growtharrested breast cancer cells: an in vitro paradigm for breast cancer dormancy in bone marrow. Cancer Res. 2004;64:4514-22.

35. Wang H, Rubin M, Fenig E, DeBlasio T, Mendelsohn J, Yahalom J, et al. Basic FGF causes growth arrest in MCF-7 human breast cancer cells while inducing both mitogenic and inhibitory $\mathrm{G}_{1}$ events. Cancer Res. 1997;57: 1750-7.

36. Najmi S, Korah R, Chandra R, Abdellatif M, Wieder R. Flavopiridol blocks integrin-mediated survival in dormant breast cancer cells. Clin Cancer Res. 2005;11:2038-46.

37. Barrios J, Wieder R. Dual FGF-2 and intergrin a5 31 signaling mediate GRAFinduced RhoA inactivation in a model of breast cancer dormancy. Cancer Microenviron. 2009;2:33-47.

38. Parrinello S, Coppe JP, Krtolica A, Campisi J. Stromal-epithelial interactions in aging and cancer: senescent fibroblasts alter epithelial cell differentiation. J Cell Sci. 2005;118(Pt 3):485-96.

39. Cheleuitte D, Mizuno S, Glowacki J. In vitro secretion of cytokines by human bone marrow: effects of age and estrogen status. Journal of Clinical Endocrinology \& Metabolism. 1998;83:2043-51.

40. Miyoshi N, Oubrahim H, Chock PB, Stadtman ER. Age-dependent cell death and the role of ATP in hydrogen peroxide-induced apoptosis and necrosis. Proc Natl Acad Sci U S A. 2006;103:1727-31.

41. Tandara AA, Kloeters O, Kim I, Mogford JE, Mustoe TA. Age effect on HSP70: decreased resistance to ischemic and oxidative stress in HDF. J Surg Res. 2006;132:32-9

42. Hall DM, Xu L, Drake VJ, Oberley LW, Oberley TD, Moseley PL, et al. Aging reduces adaptive capacity and stress protein expression in the liver after heat stress. J Applied Physiology. 2000;89:749-59.

43. Smith J, Al-Amri M, Dorairaj P, Sniderman A. The adipocyte life cycle hypothesis. Clin Sci. 2006;110:1-9.

44. Ballon D, Jakubowski AA, Tulipano PK, Graham MC, Schneider E, Aghazadeh B, et al. Quantitative assessment of bone marrow hematopoiesis using parametric magnetic resonance imaging. Magn Reson Med. 1998;39:789-800.

45. Nemeth K, Mayer B, Sworder BJ, Kuznetsov SA, Mezey E. A practical guide to culturing mouse and human bone marrow stromal cells. Current Protocols in Immunology. 2013:102:Unit 22F.12.

46. Tivari S, Korah R, Lindy M, Wieder R. An in vitro dormancy model of estrogen-sensitive breast cancer in the bone marrow: a tool for molecular mechanism studies and hypothesis generation. J Vis Exp. 2015;100:e52672.

47. Kumar S, Lu B, Dixit U, Hossain S, Liu Y, Li J, et al. Reciprocal regulation of Abl kinase by Crk Y251 and Abi1 controls invasive phenotypes in glioblastoma. Oncotarget. 2015;6:37792-807.

48. Fenig E, Kanfi Y, Wang Q, Beery E, Livnat T, Wasserman L, et al. Role of transforming growth factor beta in the growth inhibition of human breast cancer cells by basic fibroblast growth factor. Breast Cancer Res Treat. 2001;70:27-37.

49. Derynck R, Muthusamy BP, Saeteurn KY. Signaling pathway cooperation in TGF-beta-induced epithelial-mesenchymal transition. Curr Opin Cell Biol. 2014;31:56-66.

50. De Craene B, Berx G. Regulatory networks defining EMT during cancer initiation and progression. Nat Rev Cancer. 2013;13:97-110.

51. Lamouille S, Xu J, Derynck R. Molecular mechanisms of epithelialmesenchymal transition. Nat Rev Mol Cell Biol. 2014;15:178-96.

52. Tsapara A, Luthert P, Greenwood J, Hill CS, Matter K, Balda MS. The RhoA activator GEF-H1/LfC is a transforming growth factor- $\beta$ target gene and effector that regulates alpha-smooth muscle actin expression and cell migration. Mol Biol Cell. 2010;21:860-70.

53. Cheng IK, Tsang BC, Lai KP, Ching AK, Chan AW, To KF, et al. GEF-H1 overexpression in hepatocellular carcinoma promotes cell motility via activation of RhoA signalling. J Pathol. 2012;228:575-85.

54. Thiery JP, Acloque H, Huang RY, Nieto MA. Epithelial-mesenchymal transitions in development and disease. Cell. 2009;139:871-90.

55. Liu ZC, Wang HS, Zhang G, Liu H, Chen XH, Zhang F, et al. AKT/GSK-3beta regulates stability and transcription of snail which is crucial for bFGFinduced epithelial-mesenchymal transition of prostate cancer cells. Biochim Biophys Acta. 1840;2014:3096-105.
56. Korah R, Sysounthone V, Golowa Y, Wieder R. Basic fibroblast growth factor confers a more differentiated phenotype in MDA-MB-231 human breast cancer cells. Cancer Res. 2000;60:733-40.

57. Hildebrand JD, Taylor JM, Parsons JT. An SH3 domain-containing GTPaseactivating protein for rho and Cdc42 associates with focal adhesion kinase. Molecular \& Cellular Biology. 1996;16:3169-78.

58. Taylor JM, Macklem MM, Parsons JT. Cytoskeletal changes induced by GRAF, the GTPase associated with focal adhesion kinase, are mediated by rho. J Cell Sci. 1999;112:231-42

59. Wang Y, Yang J, Gao Y, Du Y, Bao L, Niu W, et al. Regulatory effect of e2, IL6 and IL-8 on the growth of epithelial ovarian cancer cells. Cellular \& Molecular Immunology. 2005;2:365-72.

60. Araki S, Omori Y, Lyn D, Singh RK, Meinbach DM, Sandman Y, et al. Interleukin-8 is a molecular determinant of androgen independence and progression in prostate cancer. Cancer Res. 2007;67:6854-62.

61. Lee SO, Chun JY, Nadiminty N, Lou W, Gao AC. Interleukin-6 undergoes transition from growth inhibitor associated with neuroendocrine differentiation to stimulator accompanied by androgen receptor activation during LNCaP prostate cancer cell progression. Prostate. 2007:67:764-73.

62. Lee LF, Louie MC, Desai SJ, Yang J, Chen HW, Evans CP, et al. Interleukin-8 confers androgen-independent growth and migration of LNCaP: differential effects of tyrosine kinases Src and FAK. Oncogene. 2004;23:2197-205.

63. Rega G, Kaun C, Demyanets S, Pfaffenberger S, Rychli K, Hohensinner PJ, et al. Vascular endothelial growth factor is induced by the inflammatory cytokines interleukin- 6 and oncostatin $m$ in human adipose tissue in vitro and in murine adipose tissue in vivo. Arteriosclerosis, Thrombosis \& Vascular Biology. 2007;27:1587-95.

64. Steiner H, Berger AP, Godoy-Tundidor S, Bjartell A, Lilja H, Bartsch G, et al. An autocrine loop for vascular endothelial growth factor is established in prostate cancer cells generated after prolonged treatment with interleukin 6. Eur J Cancer. 2004;40:1066-72.

65. Luppi F, Longo AM, de Boer WI, Rabe KF, Hiemstra PS. Interleukin-8 stimulates cell proliferation in non-small cell lung cancer through epidermal growth factor receptor transactivation. Lung Cancer. 2007;56:25-33.

66. Sriuranpong V, Park Jl, Amornphimoltham P, Patel V, Nelkin BD, Gutkind JS. Epidermal growth factor receptor-independent constitutive activation of STAT3 in head and neck squamous cell carcinoma is mediated by the autocrine/paracrine stimulation of the interleukin 6/gp130 cytokine system. Cancer Res. 2003;63:2948-56.

67. Berishaj M, Gao SP, Ahmed S, Leslie K, Al-Ahmadie H, Gerald WL, et al. Stat3 is tyrosine-phosphorylated through the interleukin-6/glycoprotein 130/Janus kinase pathway in breast cancer. Breast Cancer Res. 2007;9:R32.

68. Chang KT, Tsai CM, Chiou YC, Chiu CH, Jeng KS, Huang CY. IL-6 induces neuroendocrine dedifferentiation and cell proliferation in non-small cell lung cancer cells. American Journal of Physiology - Lung Cellular \& Molecular Physiology. 2005;289:L446-53.

69. Wehbe H, Henson R, Meng F, Mize-Berge J, Patel T. Interleukin-6 contributes to growth in cholangiocarcinoma cells by aberrant promoter methylation and gene expression. Cancer Res. 2006;66:10517-24.

70. Kobayashi S, Werneburg NW, Bronk SF, Kaufmann SH, Gores GJ. Interleukin-6 contributes to Mcl-1 up-regulation and TRAlL resistance via an Akt-signaling pathway in cholangiocarcinoma cells. Gastroenterology. 2005;128:2054-65.

71. Jee $\mathrm{SH}$, Chiu HC, Tsai TF, Tsai WL, Liao YH, Chu CY, et al. The phosphotidyl inositol 3-kinase/Akt signal pathway is involved in interleukin-6-mediated Mcl-1 upregulation and anti-apoptosis activity in basal cell carcinoma cells. J Investig Dermatol. 2002;119:1121-7.

72. Kuo ML, Chuang SE, Lin MT, Yang SY. The involvement of PI 3-K A Aktdependent up-regulation of $\mathrm{MCl}-1$ in the prevention of apoptosis of Hep3B cells by interleukin-6. Oncogene. 2001;20:677-85.

73. Poma P, Notarbartolo M, Labbozzetta M, Sanguedolce R, Alaimo A, Carina V et al. Antitumor effects of the novel NF-kappaB inhibitor dehydroxymethylepoxyquinomicin on human hepatic cancer cells: analysis of synergy with cisplatin and of possible correlation with inhibition of pro-survival genes and IL-6 production. Int J Oncol. 2006;28:923-30.

74. Luckett LR, Gallucci RM. Interleukin-6 (IL-6) modulates migration and matrix metalloproteinase function in dermal fibroblasts from IL-6KO mice. $\mathrm{Br} J$ Dermatol. 2007;156:1163-71.

75. Shih LY, Shih HN, Chen TH. Bone resorption activity of osteolytic metastatic lung and breast cancers. J Orthopaedic Research. 2004;22:1161-7.

76. Singh B, Berry JA, Vincent LE, Lucci A. Involvement of IL-8 in COX-2mediated bone metastases from breast cancer. J Surg Res. 2006;134:44-51. 
77. Zarzynska JM. Two faces of TGF-beta1 in breast cancer. Mediat Inflamm. 2014;2014:141747.

78. Massague J. TGFbeta in Cancer. Cell. 2008;134:215-30.

79. Massague J. TGFbeta signalling in context Nature Reviews Molecular Cell Biology. 2012;13:616-30.

80. Nguyen AV, Pollard JW. Transforming growth factor beta3 induces cell death during the first stage of mammary gland involution. Development. 2000;127:3107-18.

81. Siegel PM, Shu W, Cardiff RD, Muller WJ, Massague J. Transforming growth factor beta signaling impairs Neu-induced mammary tumorigenesis while promoting pulmonary metastasis. Proc National Academy Sci USA. 2003;100; 8430-5.

82. Fenig E, Wieder R, Paglin S, Wang H, Persaud R, Haimovitz-Friedman A, et al. Basic fibroblast growth factor confers growth inhibition and mitogenactivated protein kinase activation in human breast cancer cells. Clin Cancer Res. 1997;3:135-14280.

83. Wang $Q$, Maloof $P$, Wang $H$, Fenig E, Stein $D$, Nichols $G$, et al. Basic fibroblast growth factor (bFGF) downregulates BCl-2 and promotes apoptosis in MCF-7 human breast cancer cells. Exp Cell Research. 1998;238:177-87.

84. Thuault S, Valcourt U, Petersen M, Manfioletti G, Heldin CH, Moustakas A. Transforming growth factor-beta employs HMGA2 to elicit epithelialmesenchymal transition. J Cell Biol. 2006:174:175-83.

85. Ozdamar B, Bose R, Barrios-Rodiles M, Wang HR, Zhang Y, Wrana JL. Regulation of the polarity protein Par6 by TGF $\beta$ receptors controls epithelial cell plasticity. Science. 2005;307:1603-9.

86. Nelson WJ. Remodeling epithelial cell organization: transitions between frontrear and apical-basal polarity. Cold Spring Harb Perspect Biol. 2009;1:a000513.

87. Yilmaz M, Christofori G. EMT, the cytoskeleton, and cancer cell invasion. Cancer Metastasis Rev. 2009;28:15-33.

88. Derynck R, Akhurst RJ. Differentiation plasticity regulated by TGF-beta family proteins in development and disease. Nat Cell Biol. 2007;9:1000-4.

89. Seton-Rogers SE, Lu Y, Hines LM, Koundinya M, LaBaer J, Muthuswamy SK, et al. Cooperation of the ErbB2 receptor and transforming growth factor beta in induction of migration and invasion in mammary epithelial cells. Proc Natl Acad Sci U S A. 2004;101:1257-62.

90. Fruman DA, Rommel C. PI3K and cancer: lessons, challenges and opportunities. Nat Rev Drug Discov. 2014:13:140-56.

91. Shirakihara T, Horiguchi K, Miyazawa K, Ehata S, Shibata T, Morita I, et al. TGF- $\beta$ regulates isoform switching of FGF receptors and epithelialmesenchymal transition. EMBO J. 2011;30:783-95.

92. Morrison SJ, Scadden DT. The bone marrow niche for haematopoietic stem cells. Nature. 2014;505:327-34.

93. Spencer JA, Ferraro F, Roussakis E, Klein A, Wu J, Runnels JM, et al. Direct measurement of local oxygen concentration in the bone marrow of live animals. Nature. 2014;508:269-73.

Ready to submit your research? Choose BMC and benefit from:

- fast, convenient online submission

- thorough peer review by experienced researchers in your field

- rapid publication on acceptance

- support for research data, including large and complex data types

- gold Open Access which fosters wider collaboration and increased citations

- maximum visibility for your research: over $100 \mathrm{M}$ website views per year

At BMC, research is always in progress.

Learn more biomedcentral.com/submissions 